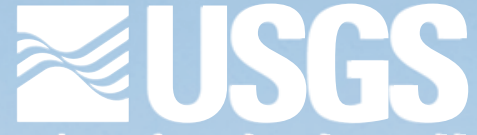

Science for a chanc nen worldy

Prepared in cooperation with the Wisconsin Department of Natural Resources

\title{
Assessment of Groundwater Trends near Crex Meadows, Wisconsin
}

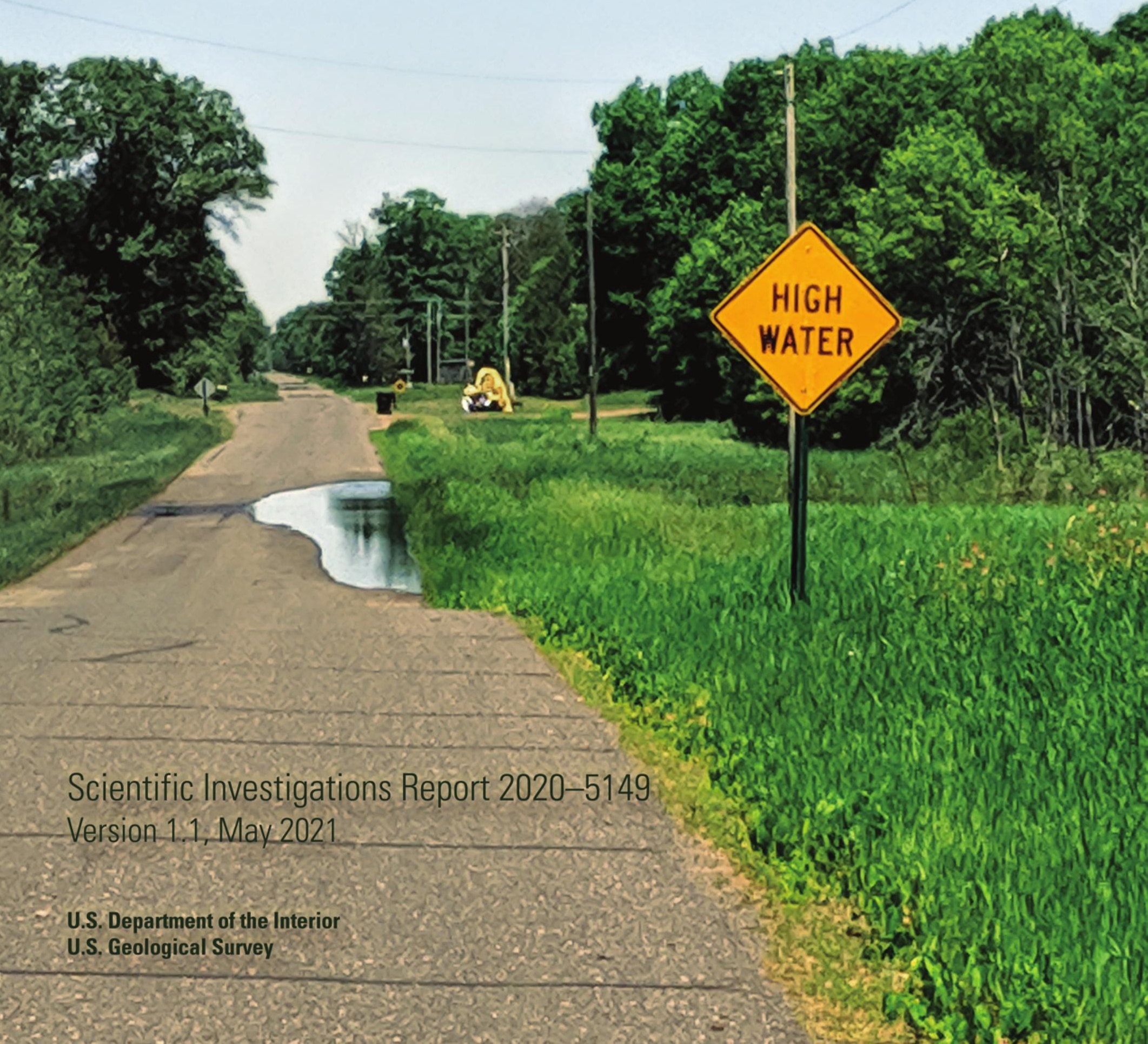


Cover. Groundwater flooding along Spaulding Road, near Grantsburg, Wisconsin. Study well 11 was installed here. Photograph by Megan J. Haserodt, U.S. Geological Survey. 


\section{Assessment of Groundwater Trends near Crex Meadows, Wisconsin}

By Megan J. Haserodt and Michael N. Fienen

Prepared in cooperation with the Wisconsin Department of Natural Resources

Scientific Investigations Report 2020-5149

Version 1.1, May 2021 


\section{U.S. Geological Survey, Reston, Virginia: 2021 First released: March 2021 \\ Revised: May 2021, ver. 1.1}

For more information on the USGS - the Federal source for science about the Earth, its natural and living resources, natural hazards, and the environment—visit https://www.usgs.gov or call 1-888-ASK-USGS.

For an overview of USGS information products, including maps, imagery, and publications, visit https://store.usgs.gov/.

Any use of trade, firm, or product names is for descriptive purposes only and does not imply endorsement by the U.S. Government.

Although this information product, for the most part, is in the public domain, it also may contain copyrighted materials as noted in the text. Permission to reproduce copyrighted items must be secured from the copyright owner.

Suggested citation:

Haserodt, M.J., and Fienen, M.N., 2020, Assessment of Groundwater Trends near Crex Meadows,

Wisconsin (ver. 1.1, May 2021): U.S. Geological Survey Scientific Investigations Report 2020-5149, 36 p., https://doi.org/10.3133/sir20205149.

ISSN 2328-0328 (online) 


\section{Acknowledgments}

The authors would like to acknowledge the Wisconsin Department of Natural Resources staff at Crex Meadows, particularly Kyle Anderson and Andrew Hawley, who worked diligently to change water levels in the flowages and collect daily flowage elevation data during the study. The study also would not have been possible without local landowners allowing wells to be installed on their properties.

Jason Smith and Lucas Stevens from the U.S. Geological Survey provided field help installing, making measurements, and removing the monitoring wells. 



\section{Contents}

Acknowledgments ……...................................................................................................................

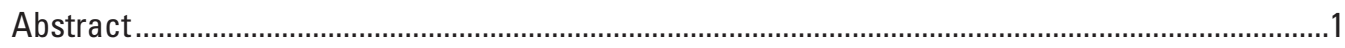

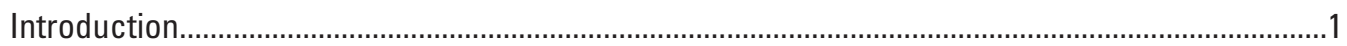

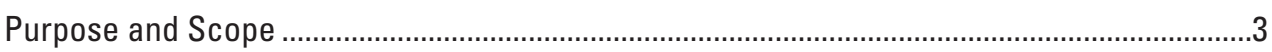

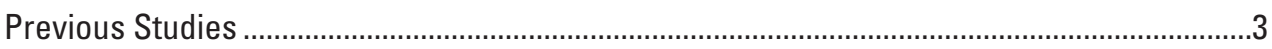

Description of the Study Area ...........................................................................................

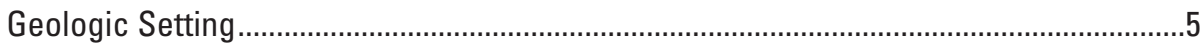

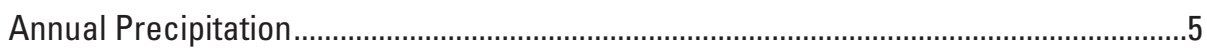

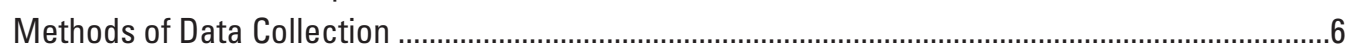

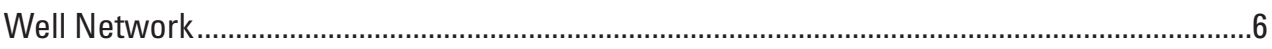

Flowage Water Levels Changes...........................................................................................

Groundwater Elevation Trend Analysis and Results ......................................................................

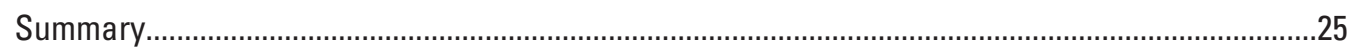

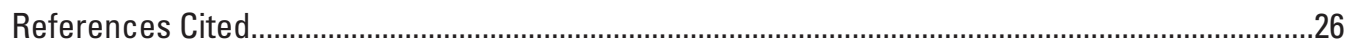

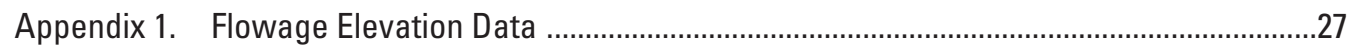

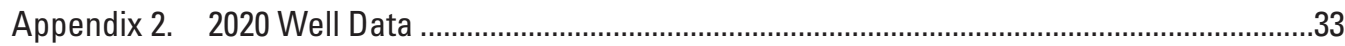

\section{Figures}

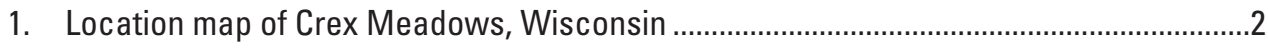

2. Monitoring well network and mapped wetlands............................................................

3. Annual precipitation at the Grantsburg, Wisconsin weather station .................................5

4. Water elevations in Dike 6 flowages and Erickson flowages at Crex ..............................8

5. Groundwater elevations for study monitoring wells...................................................

6. Scatter plots of the study well groundwater elevation and the simultaneous groundwater elevation in well WB-41 ......................................................................13

7. Scatter plots of measured and synthetic study well 5 groundwater elevation and the simultaneous groundwater elevation in well WB-41 .......................................16

8. Hydraulic gradients between each well and study well 10...........................................18

9. A schematic demonstrating the horizontal hydraulic gradient between two

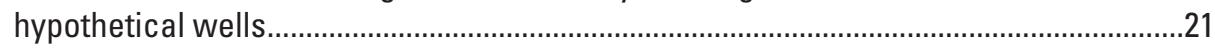

10. Departure from the mean groundwater elevation for the study period

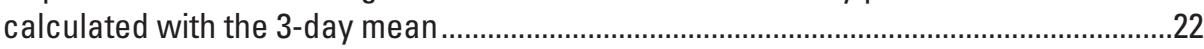

11. Cumulative departure from the mean groundwater elevation for the study period calculated with the 3-day mean .....

12. Cumulative departure from the mean groundwater elevation for the study period calculated with the 3-day average groundwater elevations for measured well 5 data and a synthetic well 5 dataset

\section{Tables}

1. Well construction details 


\title{
Conversion Factors
}

U.S. customary units to International System of Units

\begin{tabular}{lcl}
\hline & Multiply & \multicolumn{1}{c}{ To obtain } \\
\hline inch (in.) & Length & \\
inch (in.) & 2.54 & centimeter $(\mathrm{cm})$ \\
foot (ft) & 25.4 & millimeter $(\mathrm{mm})$ \\
mile (mi) & 0.3048 & meter $(\mathrm{m})$ \\
\hline & 1.609 & kilometer $(\mathrm{km})$ \\
\hline square mile $\left(\mathrm{mi}^{2}\right)$ & Area & \\
square mile $\left(\mathrm{mi}^{2}\right)$ & 259.0 & hectare $(\mathrm{ha})$ \\
& 2.590 & square kilometer $\left(\mathrm{km}{ }^{2}\right)$ \\
\hline foot per mile $(\mathrm{ft} / \mathrm{mi})$ & Hydraulic gradient & \\
\hline
\end{tabular}

\section{Datum}

Vertical coordinate information is referenced to the North American Vertical Datum of 1988 (NAVD 88). Horizontal coordinate information is referenced to the North American Datum of 1983 (NAD 83), Zone 15N.

Elevation, as used in this report, refers to distance above the vertical datum.

\section{Abbreviations}

\author{
Crex Crex Meadows Wildlife Area \\ NWIS National Water Information System \\ USGS U.S. Geological Survey \\ WDNR Wisconsin Department of Natural Resources
}




\title{
Assessment of Groundwater Trends near Crex Meadows, Wisconsin
}

\author{
By Megan J. Haserodt and Michael N. Fienen
}

\section{Abstract}

Crex Meadows Wildlife Area (Crex) is a 30,000-acre property in Burnett County, Wisconsin. Crex is managed by the Wisconsin Department of Natural Resources (WDNR) with the goal of providing public recreation opportunities while also protecting the quality of native ecological communities and species on the property. The WDNR's management strategy includes controlling water levels at flowages in Crex using a system of dikes, water control structures, ditches, and a diversion pump. For the past several decades there has been concern among nearby landowners that the water management strategy at Crex may be contributing to groundwater flooding in adjacent, privately held properties. This issue has been particularly contentious during periods when regional groundwater elevations are already high. This study was conducted in response to those concerns. For the study, a network of 12 monitoring wells was installed in and to the west of Crex. Groundwater elevations were recorded in the wells before, during, and after water-level changes in the western Crex flowages to assess if groundwater elevations to the west of Crex are detectably affected by the flowage water levels.

This study successfully collected groundwater elevations in 11 study wells during a 3-month period in 2019 when water elevations in the Dike 6 flowage and Erickson flowage were lowered and then raised. The data logger at a 12th location failed and no data were recorded. The groundwater elevation trends in these study wells were compared with groundwater elevation trends at a regional U.S. Geological Survey well to provide information for determining if changing the flowage elevations had a noticeable response in the study wells west of Crex Meadows. This analysis was done by (1) evaluating study well groundwater elevation trends compared to the regional well, (2) using a scatter plot of study well and regional well data during raising and lowering periods, (3) assessing horizontal hydraulic gradient data during the study period, and (4) assessing the cumulative departure from the mean groundwater elevation for each well.

Overall, regional groundwater elevations had a downward trend before and during the flowage lowering period and then had an upward trend during the flowage raising period. This pattern was observed in the regional well and in all the study wells adjacent to and several miles from the flowages.
The similarity in patterns indicates that precipitation and regional groundwater flow conditions were the dominant drivers of the system during the study period. The scatter plot and cumulative departure from the mean analysis showed that in addition to regional trends, wells 1, 6, and 7 were likely affected by the changes in the flowage water levels. Overall, at least on the timescale of this study, water management at Crex likely did not have detectable effects on wells outside the Crex property. Wells installed on the Crex property including the wells in the lakebeds of the flowages (wells 1 and 7) and possibly well 6 east of the flowages showed what seems to be minor affects due to water management at Crex.

\section{Introduction}

Crex Meadows Wildlife Area (Crex) is a 30,000-acre property in Burnett County, Wisconsin (fig. 1). Crex is managed by the Wisconsin Department of Natural Resources (WDNR) with the goal of providing public hunting, trapping, fishing, and other recreation opportunities while protecting the quality of native ecological communities and species on the property. To enhance wildlife habitat and to provide hunting access, the water levels at Crex are controlled in flowages using a system of dikes, water control structures, ditches, and a diversion pump (WDNR, 2018a). The annual schedule for flowage management is weather dependent, but in a typical year water levels are lowered in the spring, then raised and held high during the late growing season, and then stabilized just before winter (K. Anderson, WDNR Natural Resource Property Supervisor, oral commun., 2019).

For the past several decades, there has been concern among nearby landowners that elevated water levels in flowages at Crex may be contributing to groundwater flooding in adjacent, privately held properties. This issue has been particularly contentious during periods when regional groundwater elevations are already high. In the 1980s, abovenormal regional groundwater elevations exacerbated concerns that the flowages in Crex were flooding neighboring properties by raising local groundwater elevations. In response to these concerns, Patterson (1990) conducted a hydrologic study on behalf of the U.S. Geological Survey (USGS) to examine regional water-level trends, compare Crex water levels in the 


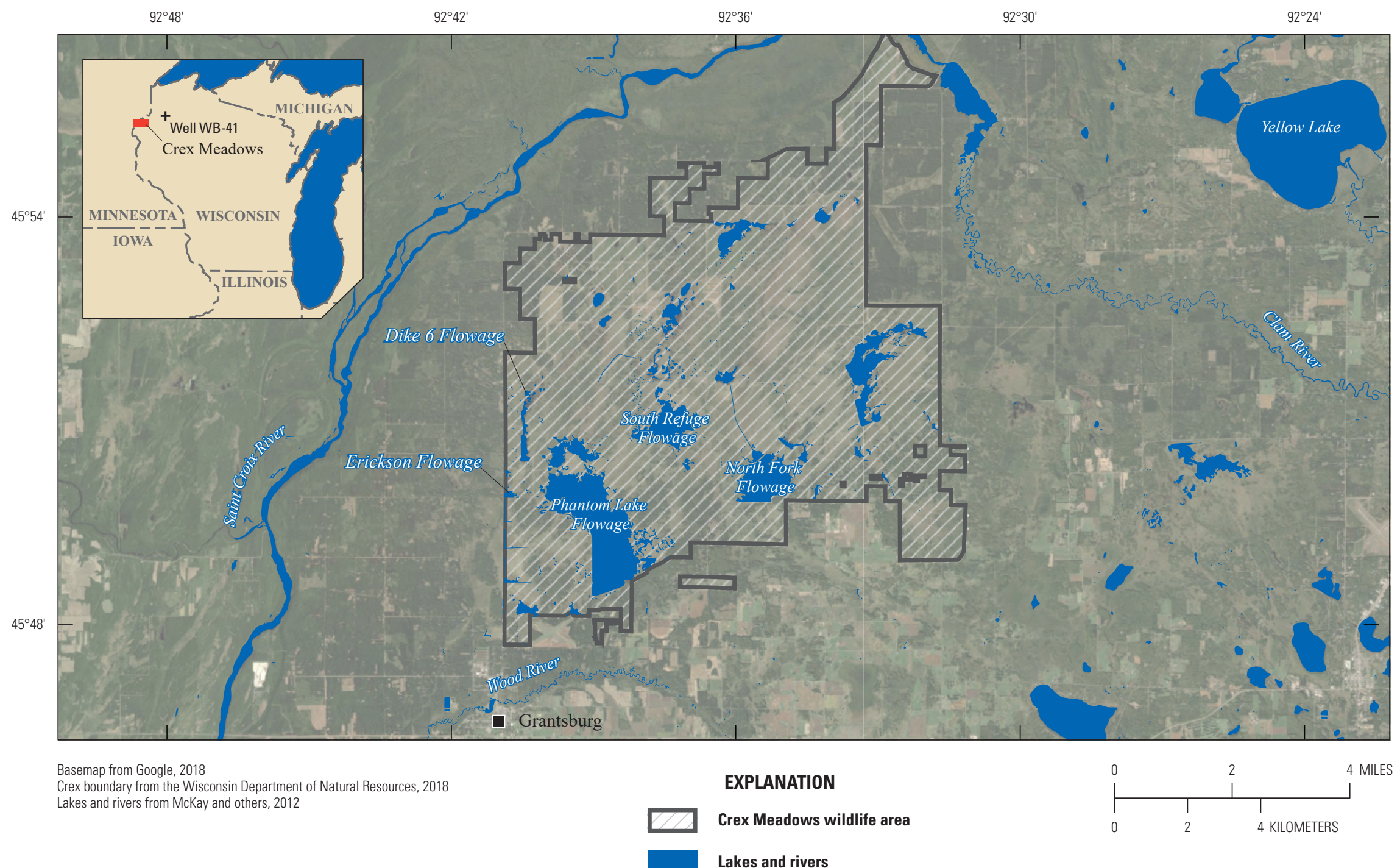

N

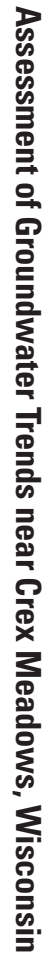

Figure 1. Location map of Crex Meadows, Wisconsin. 
1930s to levels in the 1980s, and analyze trends in discharge and precipitation records. Patterson determined that increased groundwater elevations were caused by increased precipitation (Patterson, 1990). Since the 1990 USGS study, the issue of groundwater flooding near Crex has remained contentious. With wetter-than-average conditions in recent years (WDNR, 2019), many landowners near Crex have experienced flooded basements, drinking-water quality issues, potential declines in property values, and an overall inability to fully utilize land due to saturated conditions (Richie, 2018). In August 2018, there was a public listening session in the nearby Town of West Marshland, Wisconsin, to better understand resident concerns (Richie, 2018). In fall of 2018, USGS hydrologists presented a summary of the previous 1990 USGS study at a public meeting.

This current study was conducted in response to the concerns voiced by local landowners that managed water levels in Crex contribute to groundwater flooding beyond the WDNR property. During the 1980s USGS monitored water levels in an extensive network of wells within and to the south of Crex, but limited groundwater elevation data were collected to the west of Crex where current concerns are concentrated. Furthermore, the previous USGS study did not collect groundwater elevation data specifically focused on periods of changing flowage levels. The current study established a monitoring well network to the west of Crex and recorded groundwater elevations before, during, and after water-level changes in the western Crex flowages. Groundwater elevation data measured during these periods was used to assess if groundwater to the west of Crex is detectably affected by the flowage water levels.

\section{Purpose and Scope}

The purpose of this report is to describe the (1) collection and analysis of groundwater elevation data near Crex and (2) evaluate if managed water levels in Crex have detectable effects on groundwater elevations outside the property boundary. The period of study was from June 2019 to October 2019. During this study, continuous groundwater elevation data were collected at 12 monitoring wells in and to the west of Crex (fig. 2)

\section{Previous Studies}

The only known prior study to assess groundwater flooding near Crex is the 1990 USGS study (Patterson, 1990). Other literature on groundwater flooding near comparable water-level management structures is sparse and focuses on either groundwater changes from beaver dams or groundwater responses from the installation or removal of large dams on rivers.

A study that measured groundwater levels adjacent to a beaver dam in a steep mountain valley with very coarsegrained sediment determined that the dam steepened the hydraulic gradient for 1,150 feet (ft) downstream from the dam. Failure of the beaver dam resulted in a rapid (within hours) 0.26 -ft drop in groundwater elevation at a well 2,200 ft downstream from the dam (Westbrook and others, 2006). In a different study, the removal of a 28 -ft-high man-made dam in a steep mountain valley in Montana filled with coarsegrained sediment (a minimum hydraulic conductivity of about 300 feet per day [ft/day]) showed noticeable groundwater elevation drops as much as 3.7 miles (mi) downstream from the dam (Berthelote, 2013). Though these two studies in very steep environments with highly conductive aquifers indicated noticeable responses downgradient of the dams, a study of beaver dams in low topographic relief wetlands in northern Ontario concluded that because of the flat topography, the effect of beaver dams on groundwater flow was "relatively insignificant" (Woo and Waddington, 1990, p. 229).

A general discussion (Mioduszewski, 2011) of the effect of water reservoirs on groundwater systems notes that reservoirs that raise water levels relative to predevelopment conditions will result in higher groundwater elevations in the vicinity of the reservoir. The range of groundwater responses to a reservoir is dependent on land relief, height of the dam, and hydrogeologic conditions. In general, formations with low permeability may only show responses for a few to tens of meters while formations with higher permeability may show groundwater elevation responses as much as a few hundred meters from the reservoirs. For example, raising water levels by $3.3 \mathrm{ft}$ in soils that have a hydraulic conductivity of $0.002-0.02 \mathrm{ft} /$ day (within the literature range of a silt) is estimated to affect groundwater elevations no farther than a few dozen meters (Mioduszewski, 2011). Well logs from Patterson (1990) on the western edge of Crex show that subsurface materials consist of silty sand, fine-coarse sand, and silt and clay. These finer materials are likely to be similar but slightly more permeable than the fine-grained example in Mioduszewski (2011).

In general, the literature focuses on groundwater elevation changes at sites with steep terrains and very coarse fluvial sediments or studies of large dams. These are likely poor case studies for conditions at Crex where there is low topographic relief and flowage water levels are changed on the order of a few feet. The arctic beaver dam study (Woo and Waddington, 1990) in a low topographic environment and the study of generalized reservoir effects in areas with finer sediments (Mioduszewski, 2011) suggest that for areas like Crex, where topographic relief is minimal and sediments are finer, the responses in groundwater elevations downstream from a water control feature may be minimal and limited to the area near the water control feature.

\section{Description of the Study Area}

Crex is in a relatively flat region with numerous wetlands (WDNR, 2002), as shown in figure 2. Land elevations in Crex range from over $960 \mathrm{ft}$ in the southeast to less than $920 \mathrm{ft}$ in the southwest, with a distance from east to west across the 


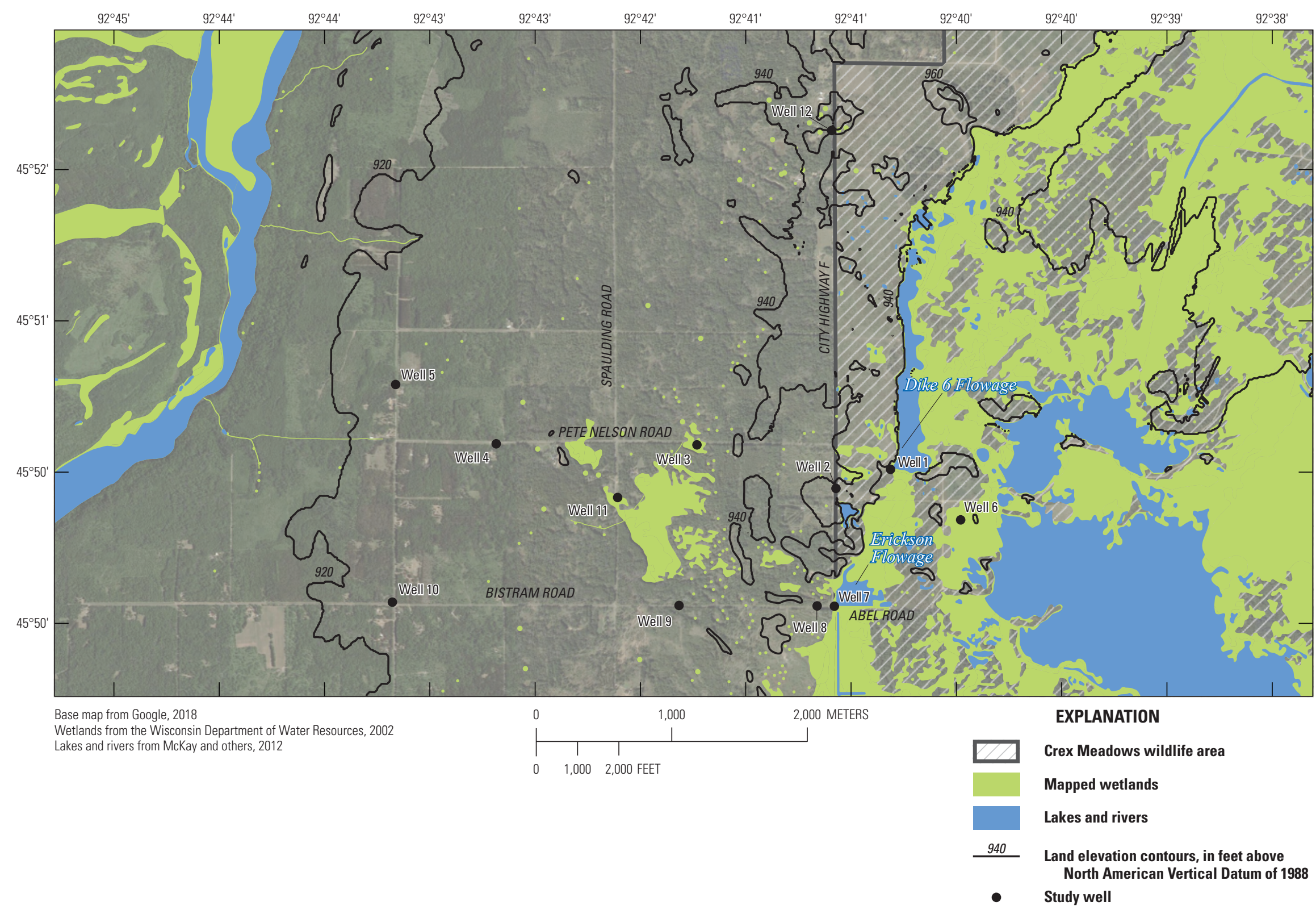

Figure 2. Monitoring well network and mapped wetlands. 
property of about $8 \mathrm{mi}$. Crex is a few miles east and south of the St. Croix River, which is the border between Minnesota and Wisconsin. The Clam River is the most prominent hydrologic feature to the east of Crex and the Wood River, which flows to the south of Crex, receives drainage from some of the flowages in Crex (fig. 1).

\section{Geologic Setting}

The shallow geologic system consists of quaternary deposits overlying sandstone bedrock (Patterson, 1990). The flat topography at Crex resulted from Glacial Lake Grantsburg, which formed in the region when the St. Croix River was dammed by the last advance of the Wisconsin glacier (WDNR, 2018a). The lake and subsequent drainages after it receded left behind the sand, silt, and clay deposits that make up the Crex Meadows Formation. The thickness of these deposits and distribution of fine-grained materials in the Crex Meadows
Formation vary spatially (Muldoon and others, 1990). As Glacial Lake Grantsburg drained it left behind smaller lakes, some of which gradually filled in with sediment and formed the numerous wetlands seen across the region today. Wind action on the exposed lakebed and beaches of Glacial Lake Grantsburg formed low sandhills and ridges across the region (Vogl, 1964).

\section{Annual Precipitation}

Average annual rainfall (2008-2019) is 34.9 inches (in.) at the Grantsburg weather station, approximately 2 miles south of Crex in the town of Grantsburg, Wisc. (fig. 1). Total annual precipitation from 2008-2019 is summarized in figure 3. The total annual precipitation in years 2014-2019 was near or above the 2008-2019 annual average. In 2019, the year this study was conducted, the annual precipitation was 42.6 in., exceeding the 2008-2019 annual average by $7.7 \mathrm{in}$.

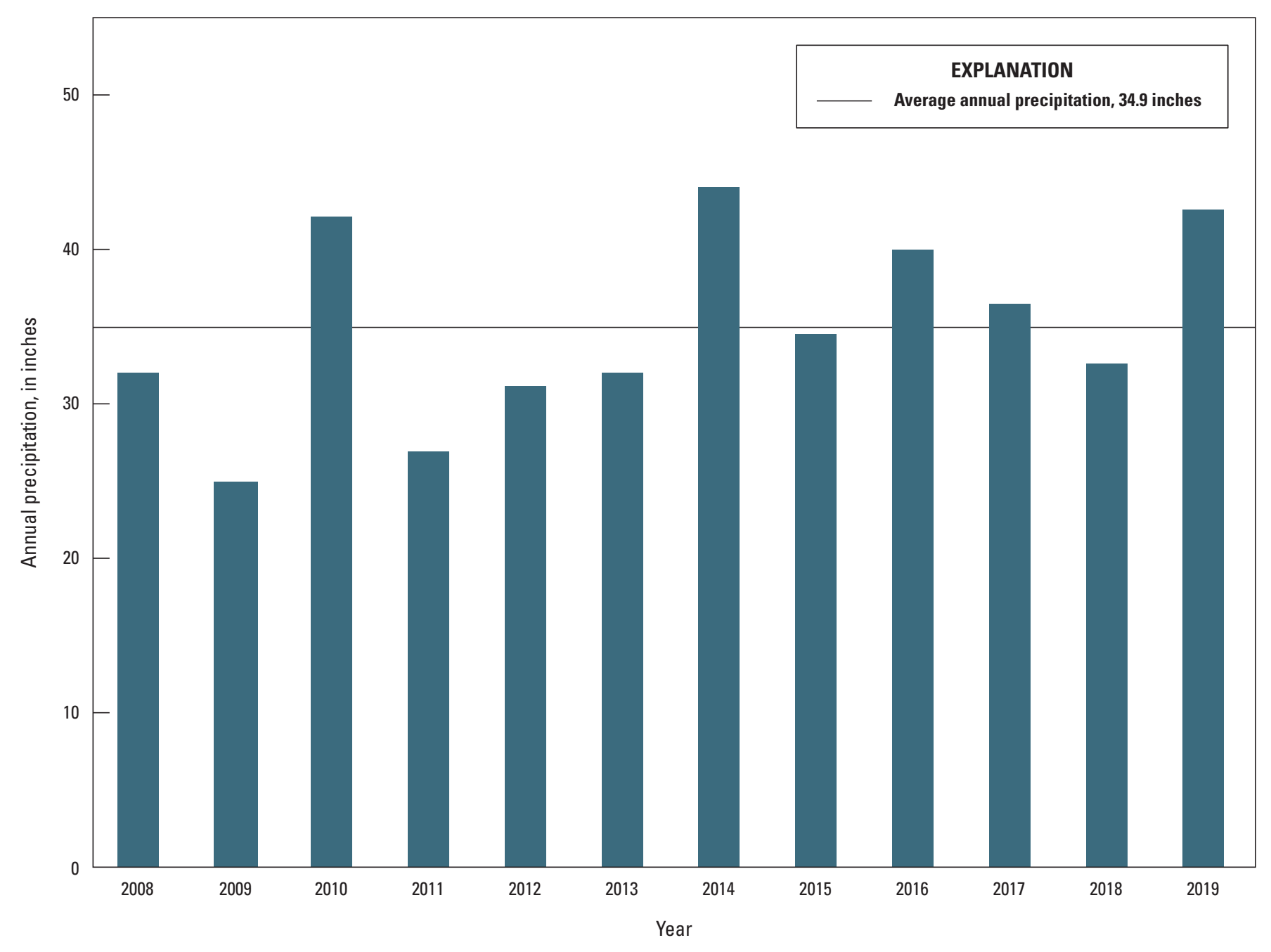

Figure 3. Annual precipitation at the Grantsburg, Wisconsin weather station (NOAA, 2020). 


\section{Methods of Data Collection}

Data collection at the site included establishing a well network, collecting continuous groundwater elevation data from the wells, and planning and monitoring flowage water-level changes.

\section{Well Network}

Twelve monitoring wells were installed for this study in June 2019. The well network generally forms two eastwest transects between Crex and the St. Croix River, roughly parallel to the assumed regional groundwater gradient from groundwater elevation highs in the east to the St. Croix River in the west. One well (well 6) was installed east of the flowages on the Crex property; two wells (wells 1 and 7) were installed in the lakebeds of the two flowages being monitored; one well (well 2) was installed within Crex but downgradient of the flowages; and eight wells were installed in upland and wetlands areas of properties to the west of Crex (fig. 2).

Wells were installed by hand in areas where the water table was near land surface and with a drill rig in upland areas. Hand-installed wells were constructed from 1/1/4-inch-diameter, threaded metal pipe risers and 1-ft-long metal, slotted screens. Hand-installed wells were pounded to depths of 7 to $8 \mathrm{ft}$ below land surface. Drilled wells were constructed from 1-inchdiameter PVC risers and 10-ft-long slotted PVC well screens. Drilled wells were completed 14 to $19 \mathrm{ft}$ below land surface. Well construction details, including the height of the riser above land surface and the total well depth, are presented in table 1. After installation, wells were developed using a pump to remove sediment fines from the well screen and establish a good hydraulic connection with the aquifer.

Groundwater elevation monitoring began in the well network on June 25 or 26, 2019. Monitoring continued through October 31, 2019. Groundwater elevations were monitored using standard USGS methods discussed in Cunningham and Schalk (2011). Continuous groundwater elevation data were collected every 15 minutes using submersible pressure transducers that record total pressure above the transducer's sensor. The total pressure includes the hydraulic pressure from the water column and the atmospheric pressure. Barometric pressure transducers were deployed in the air above the water table in the well risers to measure atmospheric pressure. The height of the water column is then equal to the total pressure logged by the pressure transducer minus the atmospheric pressure from the barometric transducer. Manual readings of depths to groundwater were also taken from a surveyed measuring point on the well casing. Water column height was converted to a groundwater elevation using these manual readings in conjunction with a simultaneous transducer reading. Manual readings were also used to compensate for any instrument drift.

All groundwater elevation data collected for this study are available in the USGS National Water Information (NWIS) database (USGS, 2019) and can be accessed using the USGS station numbers provided in table 1. Unfortunately, the logger in well 12 failed during deployment and no data were collected in this well during the 2019 season, aside from three manual readings.

Table 1. Well construction details.

[NAVD 88, North American Vertical Datum of 1988; USGS, U.S. Geological Survey; PVC, polyvinyl chloride]

\begin{tabular}{lcccccccc}
\hline $\begin{array}{c}\text { Well } \\
\text { name }\end{array}$ & $\begin{array}{c}\text { USGS Station } \\
\text { number }\end{array}$ & $\begin{array}{c}\text { Latitude, } \\
\text { decimal } \\
\text { degrees }\end{array}$ & $\begin{array}{c}\text { Longitude, } \\
\text { decimal } \\
\text { degrees }\end{array}$ & $\begin{array}{c}\text { Land } \\
\text { elevation } \\
\text { (feet above } \\
\text { NAVD 88) }\end{array}$ & $\begin{array}{c}\text { Height of } \\
\text { casing above } \\
\text { land surface } \\
\text { (feet) }\end{array}$ & $\begin{array}{c}\text { Total } \\
\text { depth of } \\
\text { well (feet) }\end{array}$ & $\begin{array}{c}\text { Length of } \\
\text { screen } \\
\text { (feet) }\end{array}$ & $\begin{array}{c}\text { Well riser } \\
\text { and screen } \\
\text { material }\end{array}$ \\
\hline Well 1 & 455025092403501 & 45.84019 & -92.67626 & 935.8 & 4.48 & 11.3 & 1 & Metal \\
Well 2 & 455020092405301 & 45.83893 & -92.68144 & 935.2 & 3.75 & 11.29 & 1 & Metal \\
Well 3 & 455031092414101 & 45.84181 & -92.69464 & 929.4 & 3.67 & 11.15 & 1 & Metal \\
Well 4 & 455031092424901 & 45.84188 & -92.7137 & 922.5 & 3.27 & 11.3 & 1 & Metal \\
Well 5 & 455045092432401 & 45.8458 & -92.72325 & 921.5 & 2.17 & 17.52 & 10 & PVC \\
Well 6 & 455013092401101 & 45.83685 & -92.6696 & 933.0 & 3.5 & 11.3 & 1 & Metal \\
Well 7 & 454952092405401 & 45.83114 & -92.68159 & 929.4 & 3.3 & 11.3 & 1 & Metal \\
Well 8 & 454952092406001 & 45.83116 & -92.68323 & 934.9 & 1.65 & 16.54 & 10 & PVC \\
Well 9 & 454952092414701 & 45.83119 & -92.69634 & 931.5 & 1.91 & 15.94 & 10 & PVC \\
Well 10 & 454953092432501 & 45.83141 & -92.72356 & 920.0 & 2.05 & 21.54 & 10 & PVC \\
Well 11 & 455018092420801 & 45.83833 & -92.70217 & 928.4 & 3.4 & 11.3 & 1 & Metal \\
Well 12 & 455145092405501 & 45.86249 & -92.68185 & 934.9 & 4.12 & 11.3 & 1 & Metal \\
\hline
\end{tabular}




\section{Flowage Water Levels Changes}

This study was designed to assess potential changes in groundwater elevations in the monitoring well network in response to changes in water levels in two managed flowages - Dike 6 flowage and Erickson flowage - near the western boundary of Crex. Water levels in the Dike 6 and Erickson flowages were lowered for the first part of the study period and then subsequently raised for the second part of the study. The WDNR staff conducted the water-level changes using a series of outlet structures with boards that can be either added or removed to manipulate the flowage water level. It is important to note that the Dike 6 flowage drains into Erickson flowage, so the management of the Dike 6 flowage affects the water levels in Erickson flowage. For example, when Dike 6 flowage is lowered, that water drains through an outlet into a tributary that then flows into the Erickson flowage.

During and before the study, WDNR staff collected water elevations at staff gages they maintain in both flowages (fig. 4). The flowage elevations in this report are from that WDNR dataset (K. Anderson, WDNR Natural Resource Property Supervisor and A. Hawley, Wildlife TechnicianAdvanced, written commun., 2019) and use the WDNR elevations of the staff gages. A table of the flowage elevation data is provided in Appendix 1. Before the start of the study, the average Dike 6 flowage water elevation was $935.4 \mathrm{ft}$ (from June 19, 2018, to July 15, 2019) and the average Erickson flowage water elevation was $929.5 \mathrm{ft}$ (from May 5, 2019, to July 15, 2019). Flowage water elevations were kept relatively stable in the months before the study.

Water levels in the flowages were lowered starting on July 15,2019 . The total water-level drop in both flowages was at least $2 \mathrm{ft}$, relative to their average water-level conditions before lowering. The Erickson flowage water level was then raised starting on August 29, 2019, and the Dike 6 flowage water level was raised starting on September 5, 2019. The flowages were raised at slightly different times because the Dike 6 flowage drains into Erickson flowage, so the Erickson flowage was allowed to fill for a few days before adding boards and filling the Dike 6 flowage. The Dike 6 and Erickson flowages were both raised approximately $4 \mathrm{ft}$ higher than their lowered condition. The raising period continued until late October 2019 when water levels in the flowages were then lowered back to average late-fall levels. In total, the lowering period and raising period each lasted approximately 1.5 months. A time series of the flowage water elevation data collected by the WDNR is presented in figure 4. Additional data were collected during a lowering period in the spring of 2020 and are included in Appendix 2.

\section{Groundwater Elevation Trend Analysis and Results}

The groundwater elevations at the study monitoring wells were compared to trends in the USGS well WB-41 (USGS site no. 460039091500101; fig. 1). Groundwater elevation trends in WB-41 are considered representative of regional groundwater conditions. Trends in study wells closest to the flowages were also compared with study wells further away from the flowages. The goal of the analysis was to look for any detectable deviations in study well trends from regional trends, which are assumed to be driven by precipitation and regional groundwater flow patterns. Deviations in groundwater level trends during the study period - particularly those that are most pronounced in wells closest to the flowages - would be indicative of groundwater elevation responses from changing the flowage elevations.

The groundwater elevation records for the 11 study wells with continuous groundwater elevation data are presented in figure 5. For wells 1 and 7, located in the lakebeds of Dike 6 and Erickson flowages, respectively, the flowage elevation is included to compare vertical gradients between the well and the flowage. The precipitation record from the Grantsburg station (NOAA, 2020) is included in figure 5 to show how groundwater elevations responded to rain events. The groundwater elevations in regional well WB-41 are included in figure 5 to show regional groundwater level trends during the same period. Dashed vertical lines are included to show when the flowages were either raised or lowered. The flowages were lowered at the same time at the beginning of the study but were later lowered and then raised at slightly different times; both sets of raising and lowering lines are shown on the plots.

In general, the study wells and the regional well showed a downward trend before lowering water levels in the flowages. This regional downward trend continued throughout the lowering period. Close to when the flowages were raised, the regional trend in WB-41 also reversed to an upward trend, likely in response to precipitation patterns. Ideally, the timing of the flowage lowering and raising periods would not have coincided so closely with changes in the regional trend in groundwater elevations. Based on the groundwater elevations observed in well WB-41, 42 mi northeast of the study site, the overall timing of the upward and downward trends observed in the study site is most likely dominantly driven by precipitation and the regional groundwater system. Further analysis of groundwater elevation data was conducted to determine if study well water elevations showed additional responses due to flowage water-level changes, beyond the effect of regional groundwater trends. The methods and results of these analyses are presented later in this section of the report. 

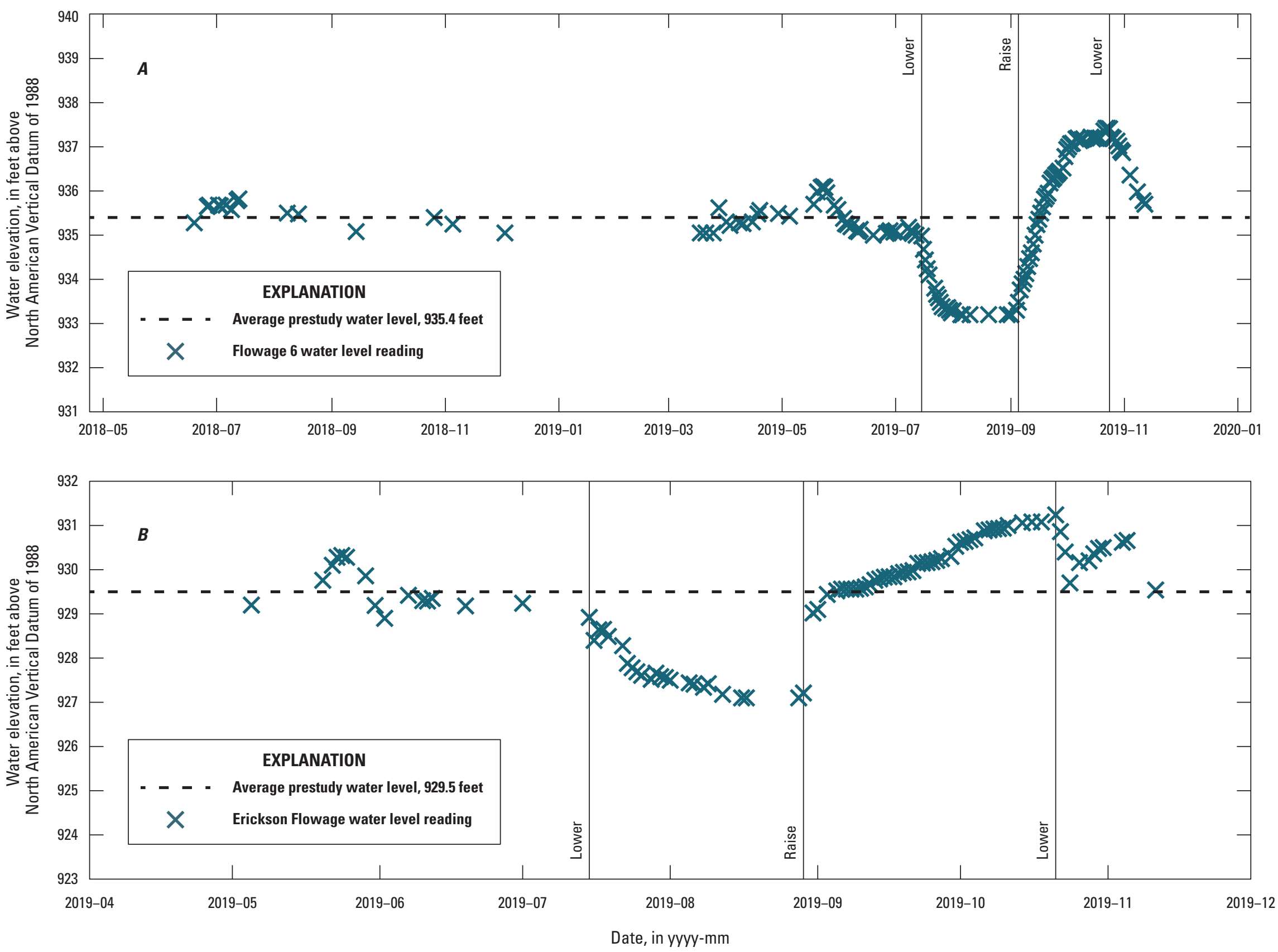

Figure 4. Water elevations in Dike 6 flowages and Erickson flowages at Crex. Water elevation data were collected and provided by the Wisconsin Department of Natural Resources (A. Hawley, Wisconsin Department of Natural Resources Wildlife Technician, written commun., 2019). Elevations below 933.3 feet for Dike 6 were below the staff gage and are estimated. 

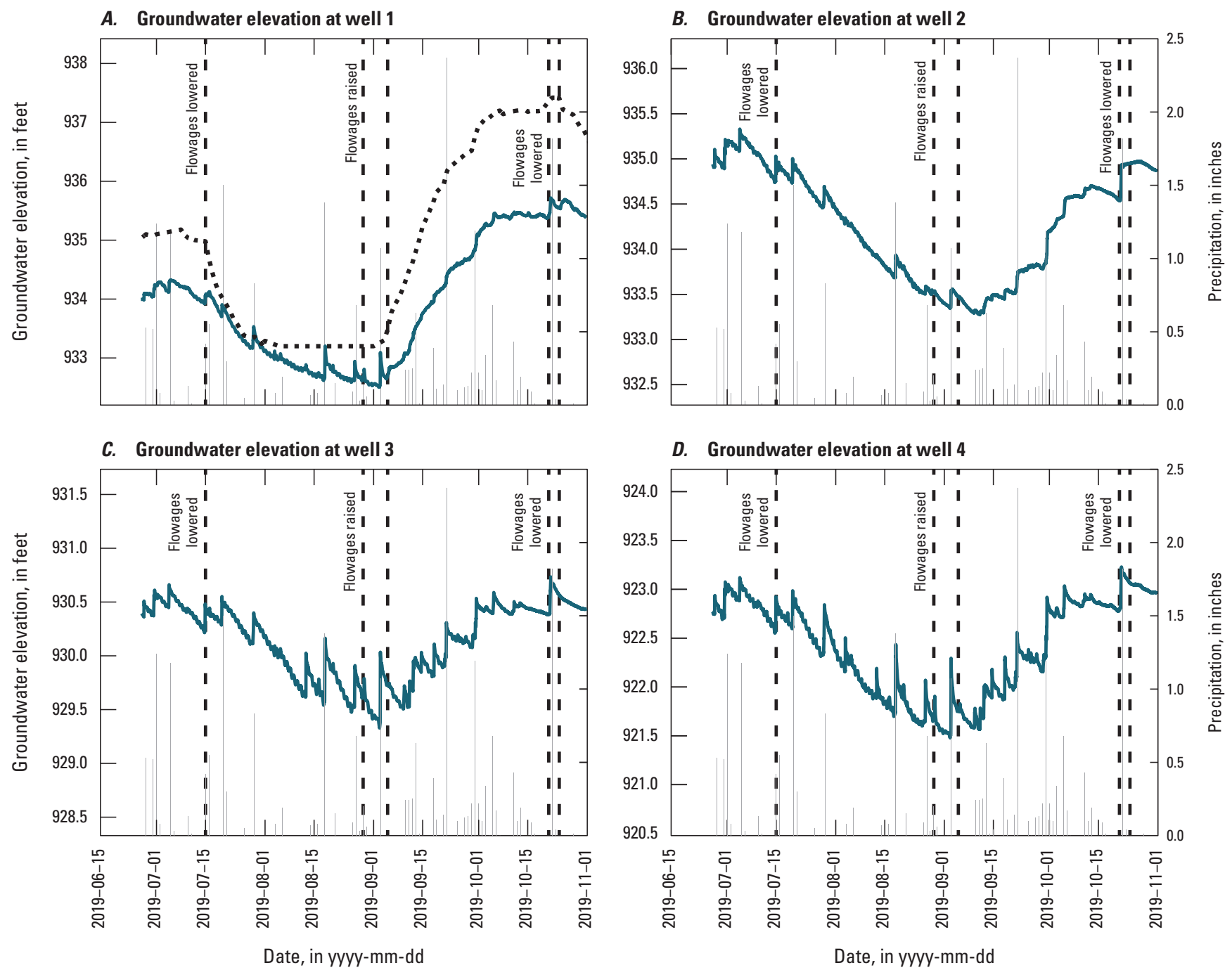

EXPLANATION

Flowage 6 water level

Precipitation at Grantsburg Station

Figure 5. Groundwater elevations for study monitoring wells. Flowage elevations are included on the plots for well 1 and well 7, which are installed in the flowage lakebeds. Groundwater elevation data from a regional well (WB-41) are also plotted. Daily precipitation is included on a secondary $\mathrm{y}$-axis to show how when wells respond to rain events. 

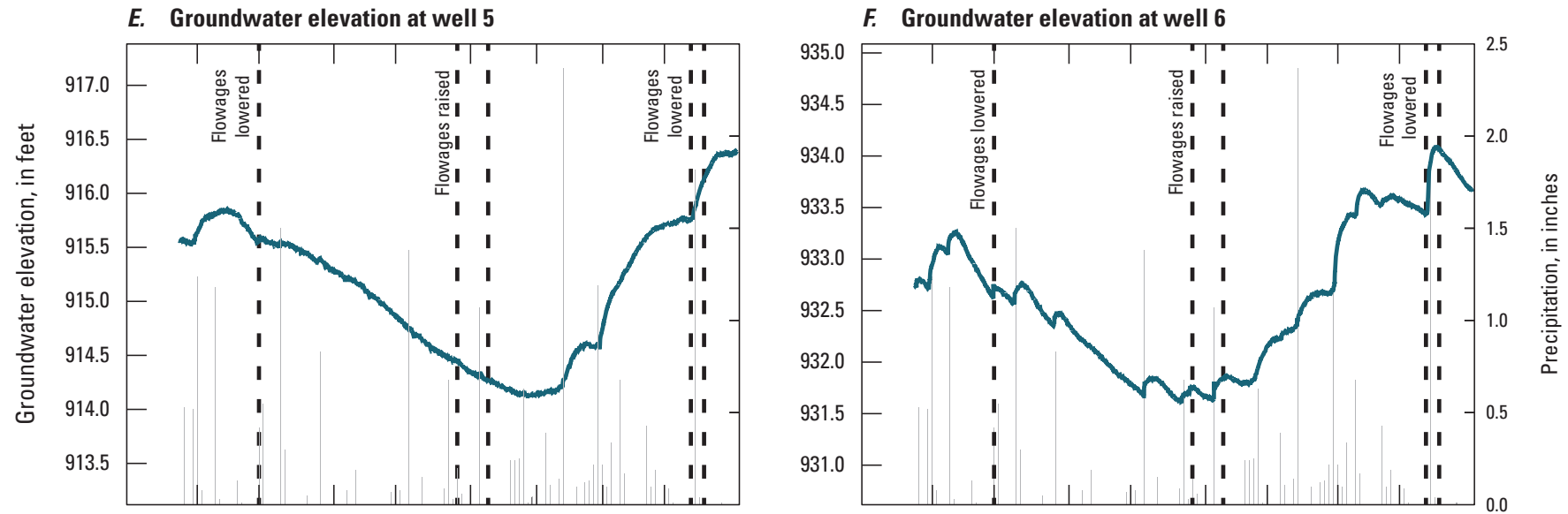

G. Groundwater elevation at well 7

H. Groundwater elevation at well 8
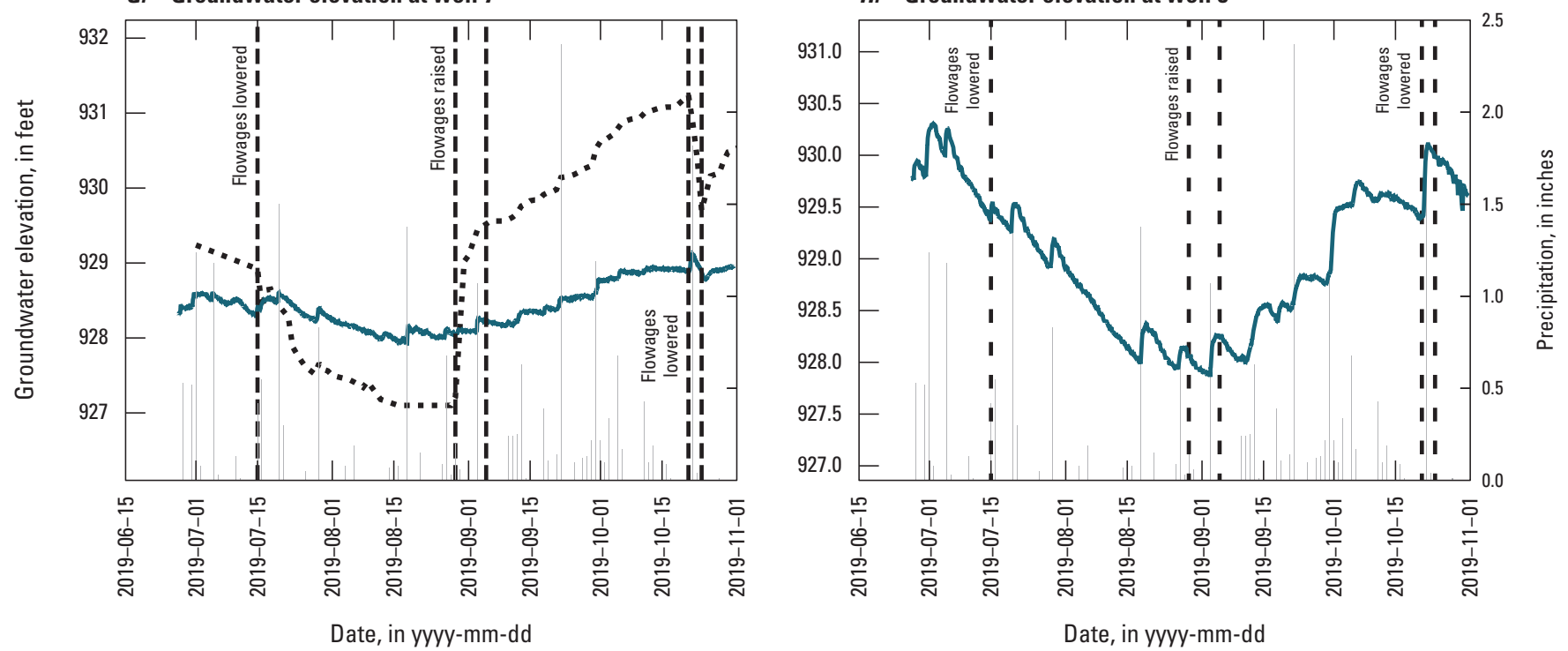

EXPLANATION

Erickson flowage water level

Precipitation at Grantsburg Station

Figure 5. Groundwater elevations for study monitoring wells. Flowage elevations are included on the plots for well 1 and well 7, which are installed in the flowage lakebeds. Groundwater elevation data from a regional well (WB-41) are also plotted. Daily precipitation is included on a secondary y-axis to show how when wells respond to rain events.-Continued 
Groundwater elevation at well 9

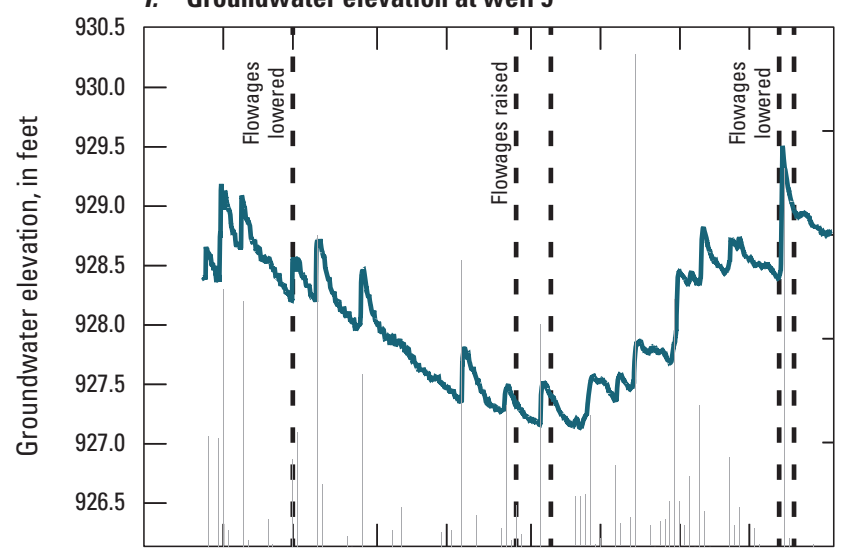

K. Groundwater elevation at well 11

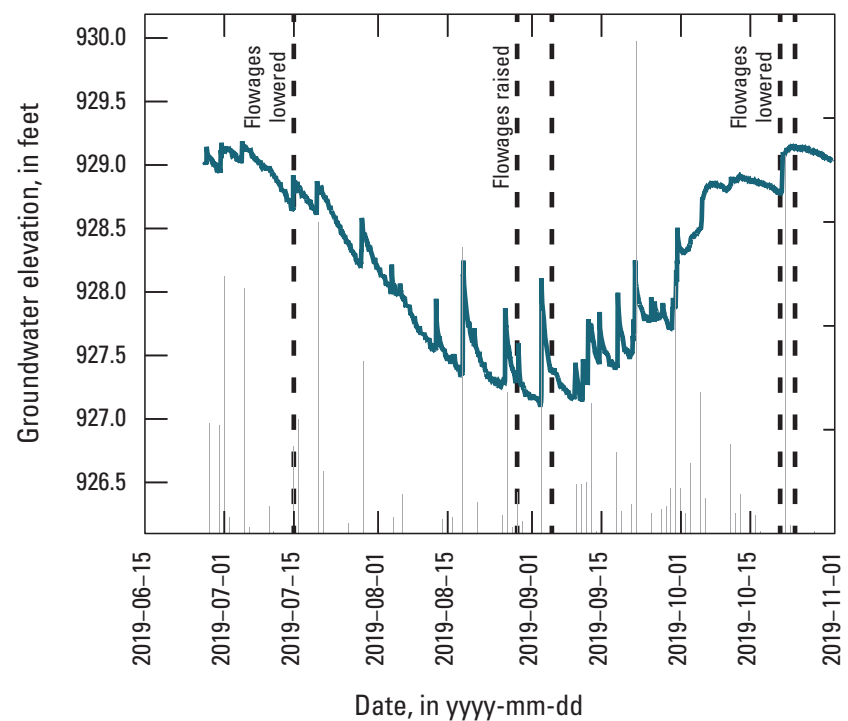

J. Groundwater elevation at well 10

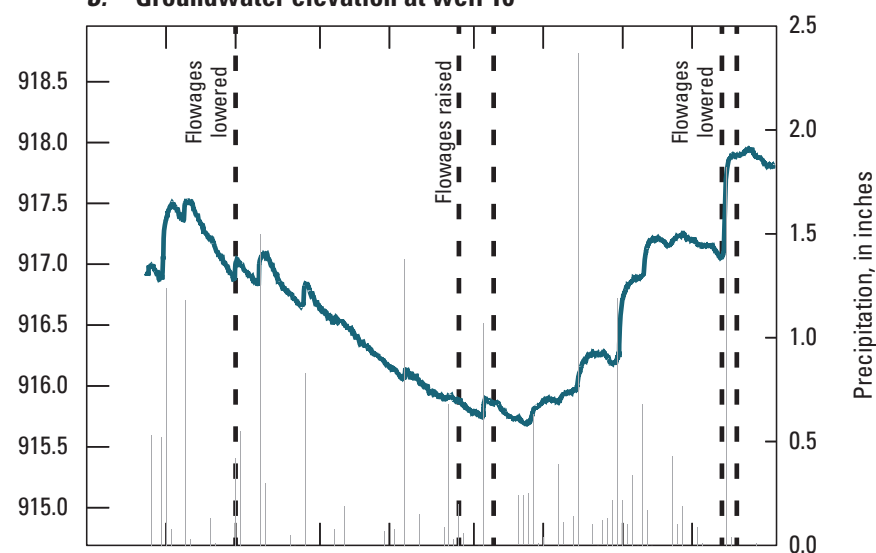

L. Groundwater elevation at well USGS reference well WB-41

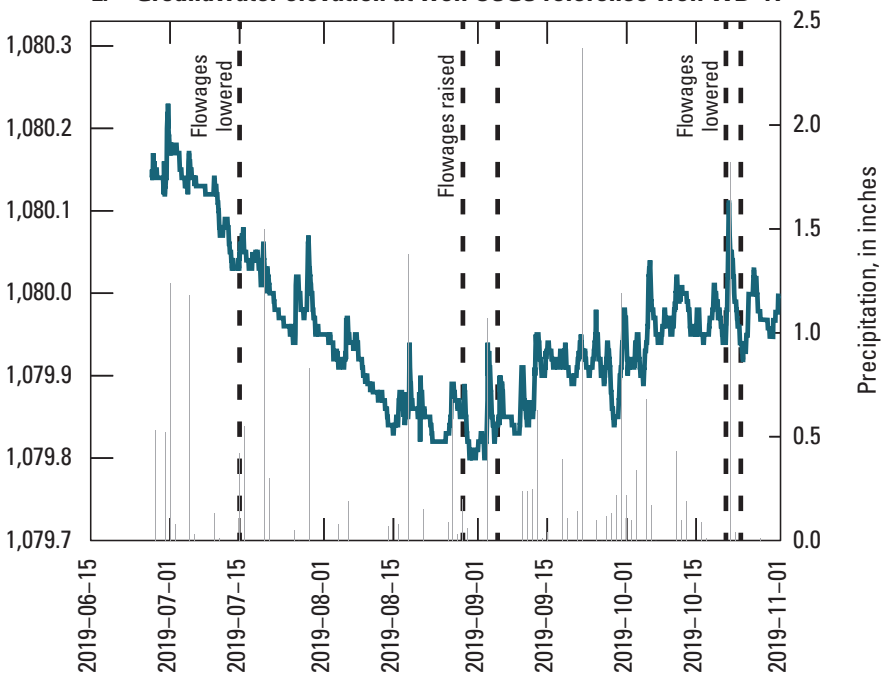

Date, in yyyy-mm-dd

EXPLANATION

Groundwater elevation in well

Date flowages raised or lowered

Precipitation at Grantsburg Station

Figure 5. Groundwater elevations for study monitoring wells. Flowage elevations are included on the plots for well 1 and well 7, which are installed in the flowage lakebeds. Groundwater elevation data from a regional well (WB-41) are also plotted. Daily precipitation is included on a secondary y-axis to show how when wells respond to rain events. - Continued 
In general, wells installed in wetlands (wells 3,4 , and 11) showed a larger groundwater elevation response to rain events than wells not installed in wetlands. Deeper wells (wells 5, 8, 9,10 , and WB-41) showed a more muted increase in groundwater elevation after rain events. The groundwater elevations in wells installed in the flowage lakebeds (wells 1 and 7) generally followed the regional groundwater elevation trend observed in well WB-41 but the difference in water elevation between the lakebed wells and the flowages changed during the study period. Before the study, the average water levels in both flowages were above the water table. At these levels, the flowages are likely discharging water into the groundwater system. The groundwater elevation in well 1 (screened in the sediment under the Dike 6 flowage) remained below the flowage water elevation for the entire study. This indicates that water is infiltrating from the flowage to the groundwater system. The difference in water elevations between the flowage and well was approximately $1 \mathrm{ft}$ before the water levels were lowered in the flowage. The difference in water elevations between the well and Dike 6 flowage was reduced during the lowering period, but this difference increased to almost $2 \mathrm{ft}$ during the raising period. The separation between the flowage water elevation and groundwater elevation indicates that the Dike 6 flowage - at least on the southern end - is likely perched above the water table. This perching is possibly due to fine-grained lakebed materials impeding the downward movement of water in the flowage to the water table. A similar relation between the groundwater system and the flowage water levels was observed at well 7 (screened in the sediments below Erickson flowage), except that during the lowering period the flowage water elevation dropped below the groundwater elevation and the flowage likely started to receive inflow from the groundwater system.

To better assess if - in addition to the regional trends observed at all the study wells - there were also groundwater elevation responses from raising and lowering the flowages, the following three methods were used to further analyze the well data: (1) a scatter plot comparison of the study well groundwater elevation and the simultaneous groundwater elevation in well WB-41 during flowage raising and lowering periods; (2) a comparison of the horizontal hydraulic gradient between the study wells and well 10, one of two study wells located the farthest away from the flowages; and (3) an analysis of the cumulative departure from the mean groundwater elevation for the period of record. For all three methods, the well groundwater elevation data were resampled to a 3-day mean to remove small, daily oscillations in the dataset and to provide a clearer measure of sustained differences.

Figure 6 shows a scatter plot of the 3-day mean groundwater elevation at each study well plotted against the simultaneous groundwater elevation in regional well WB-41. Data from the flowage lowering and raising periods are plotted in different colors. A trendline was calculated separately for the lowering period, the raising period, and both periods together. Included on figure 6 graphs are equations for those trendlines and their R-squared values, an estimate of how well the line fits the data. If the regional well and the study well were responding to the same stresses, the points from the falling and raising periods should plot in a similar pattern, the three trendlines should have similar slopes, and the $\mathrm{R}$-squared values should be similar and close to 1 , which indicates a good fit with the dataset. R-squared values decrease as data are more scattered and difficult to fit with a single line. Noticeably different patterns during the raising and lowering periods indicates that groundwater elevations at the study well are affected by stresses beyond those reflected in the regional trends (for example, stresses caused by raising and lowering flowage water levels). Smaller deviations between the raising and lowering periods are likely indicative of slightly different precipitation responses experienced by the regional and local well, partially due to distance between them and well depths.

Figure 7 shows scatter plots of measured and synthetic 3-day mean groundwater elevation for well 5-a study well that is farthest from the flowages and least likely to show a groundwater elevation response - plotted against the simultaneous groundwater elevation in regional well WB-41. The synthetic data were generated by applying a $1-\mathrm{ft}$ drop in water levels to the measured well 5 data during the initial flowage lowering period and followed by a 2 -ft rise in water levels during the flowage raising period. The synthetic data represents a 1-ft decline from prestudy water levels and then a rise to $1-\mathrm{ft}$ above prestudy levels. The water-level changes were assumed to start after a 7-day period (representing a delay between the flowage changes and effects showing up at a well), were applied linearly during 2 weeks, and then assumed to be fully present for any time remaining in the lowering and raising periods. Figure 7 includes a graph of the original well 5 data and the synthetic data generated by applying these synthetic changes in well water levels. This synthetic example is included to illustrate how a response to changing flowage elevations may appear in the scatter plots. The biggest difference between the measured and synthetic well 5 scatter plots is a noticeable $\mathrm{V}$-shaped gap on the right side of the graph between the rising and falling lines. Such a gap is interpreted to be indicative of possible stresses beyond those reflected in the regional trends (for example, stresses caused by raising and lowering flowage water levels). The synthetic groundwater elevation changes also result in a significant lowering of the R-squared value from 0.66 to 0.52 for the all data regression line.

For most of the study wells, the data points during the flowage raising and lowering periods plot close together and form a similar "X" pattern between the trendlines for the raising and lowering periods. The R-squared values for the all data regression line and the raising period regression line are similar for most of the wells. The similar R-squared values between data from one of the periods and the full dataset indicate that the overall dataset does not show trends that are significantly different from one of the single periods. These similar patterns indicate that both the study well and the regional well experienced similar stresses during the lowering and raising periods and that stresses caused by flowages 

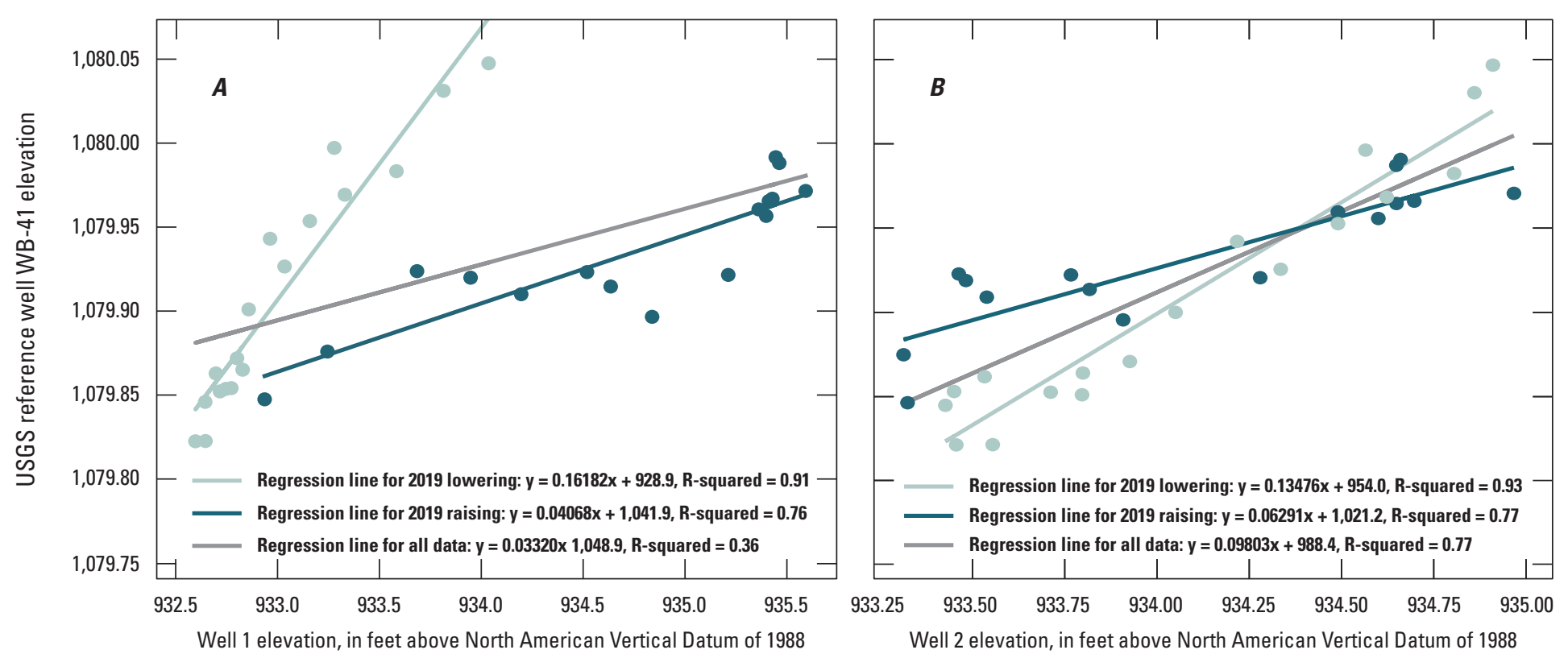

EXPLANATION

Elevation is in feet above North American Vertical Datum of 1988]

2019 falling

- 2019 rising

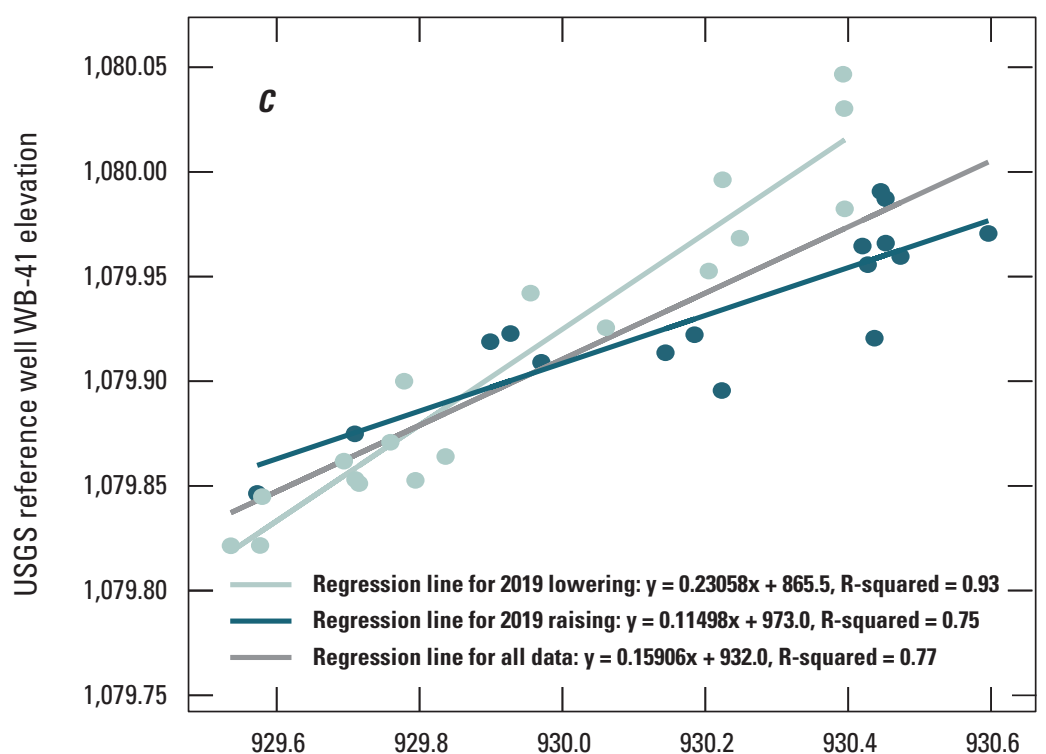

Well 3 elevation, in feet above North American Vertical Datum of 1988

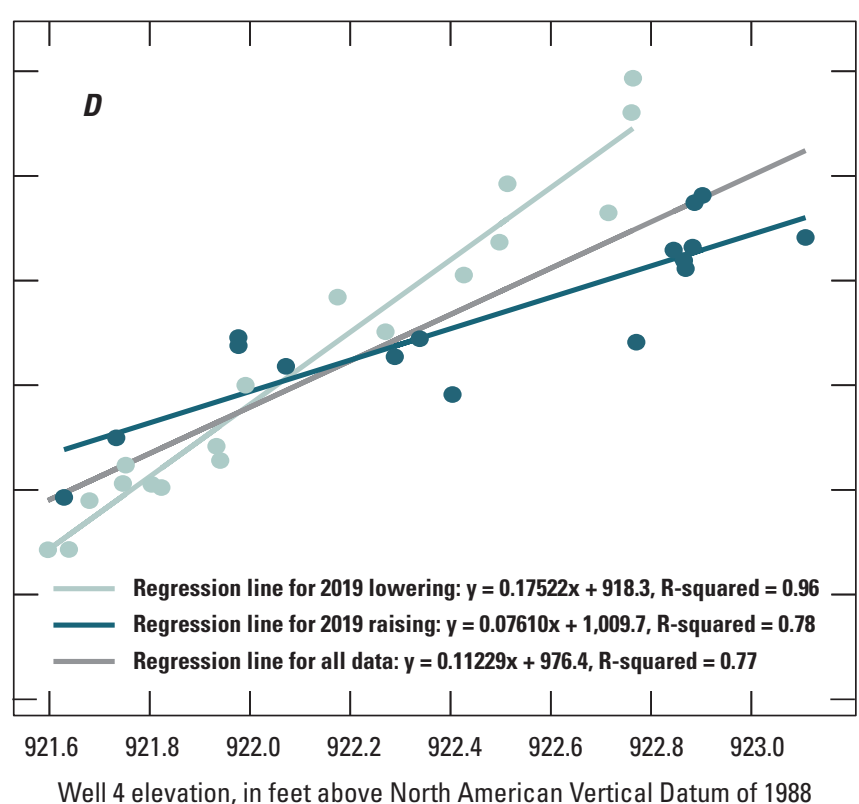

Figure 6. Scatter plots of the study well groundwater elevation and the simultaneous groundwater elevation in well WB-41, both resampled to 3-day means. 

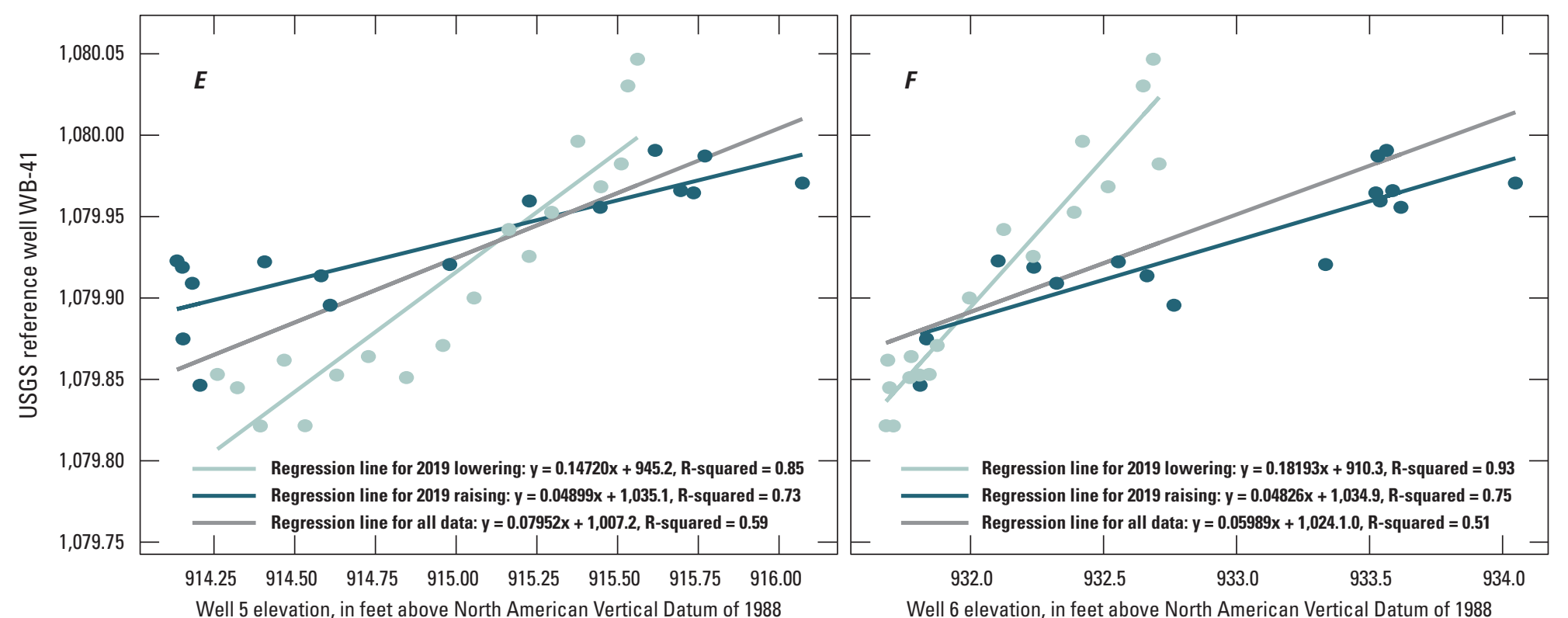

EXPLANATION

[Elevation is in feet abov Datum of 1988]

2019 falling

- 2019 rising

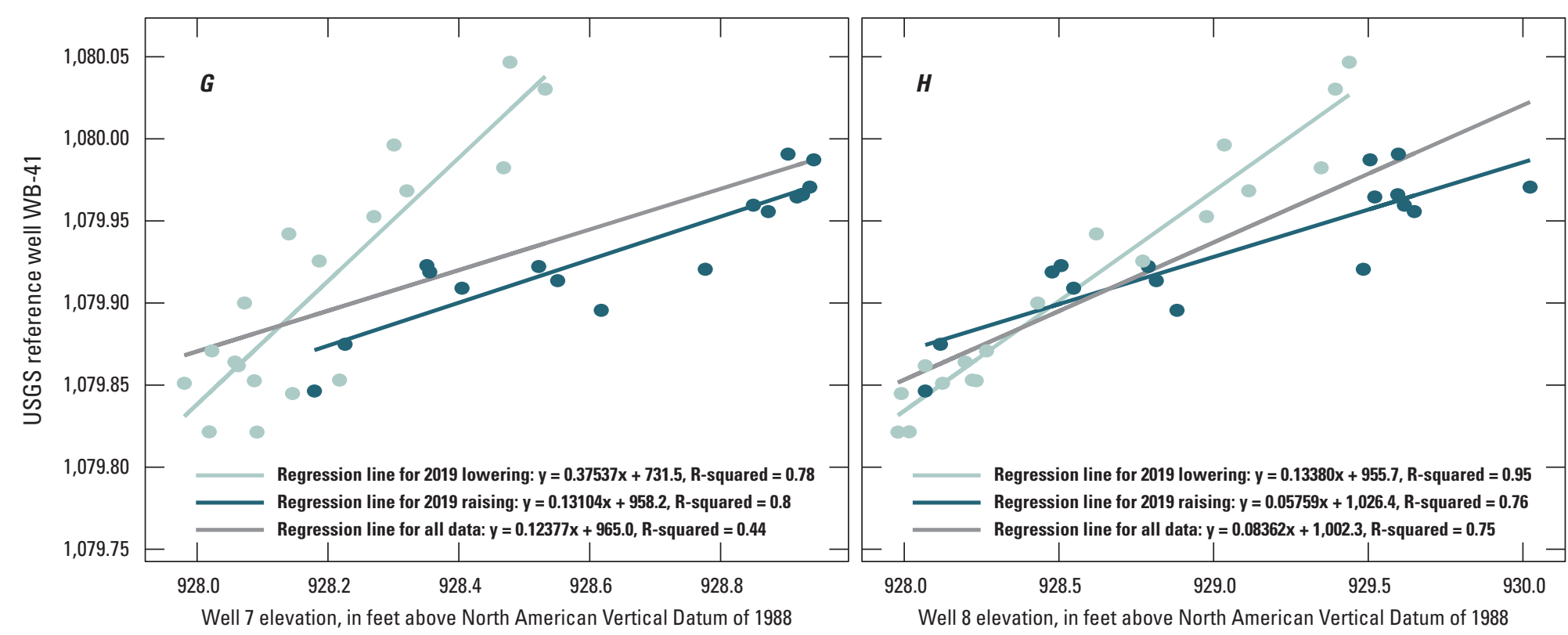

Figure 6. Scatter plots of the study well groundwater elevation and the simultaneous groundwater elevation in well WB-41, both resampled to 3-day means.-Continued 


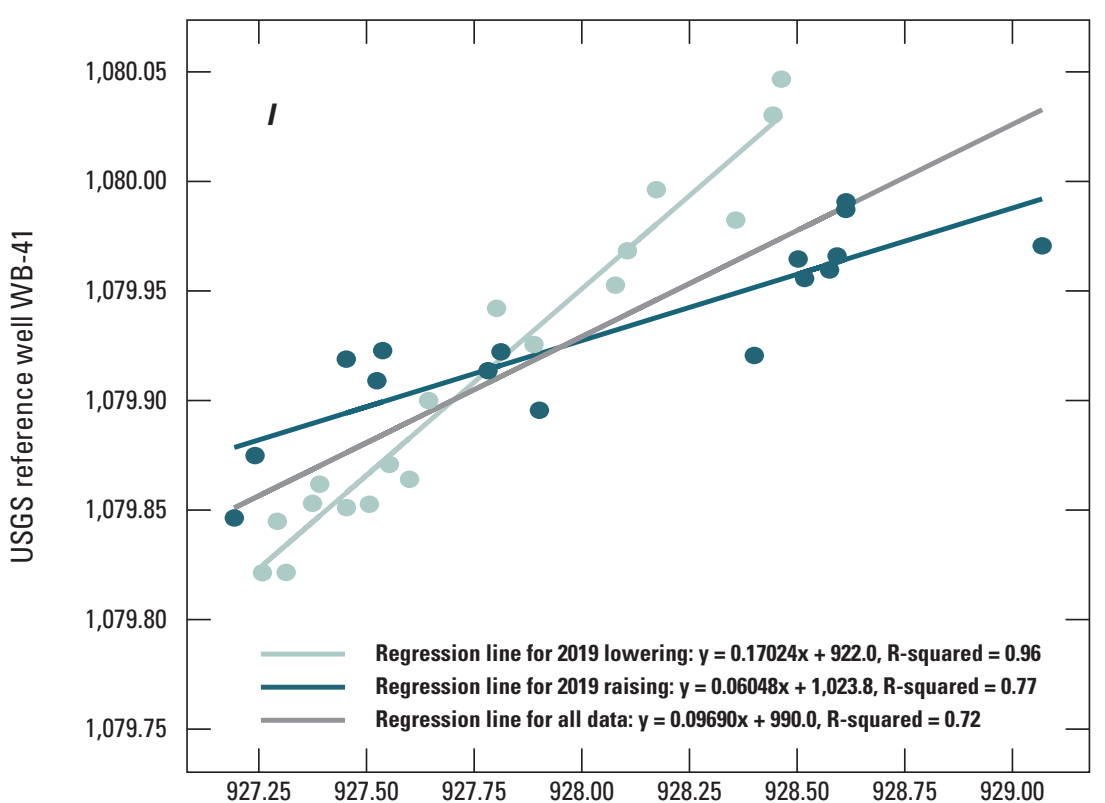

Well 9 elevation, in feet above North American Vertical Datum of 1988

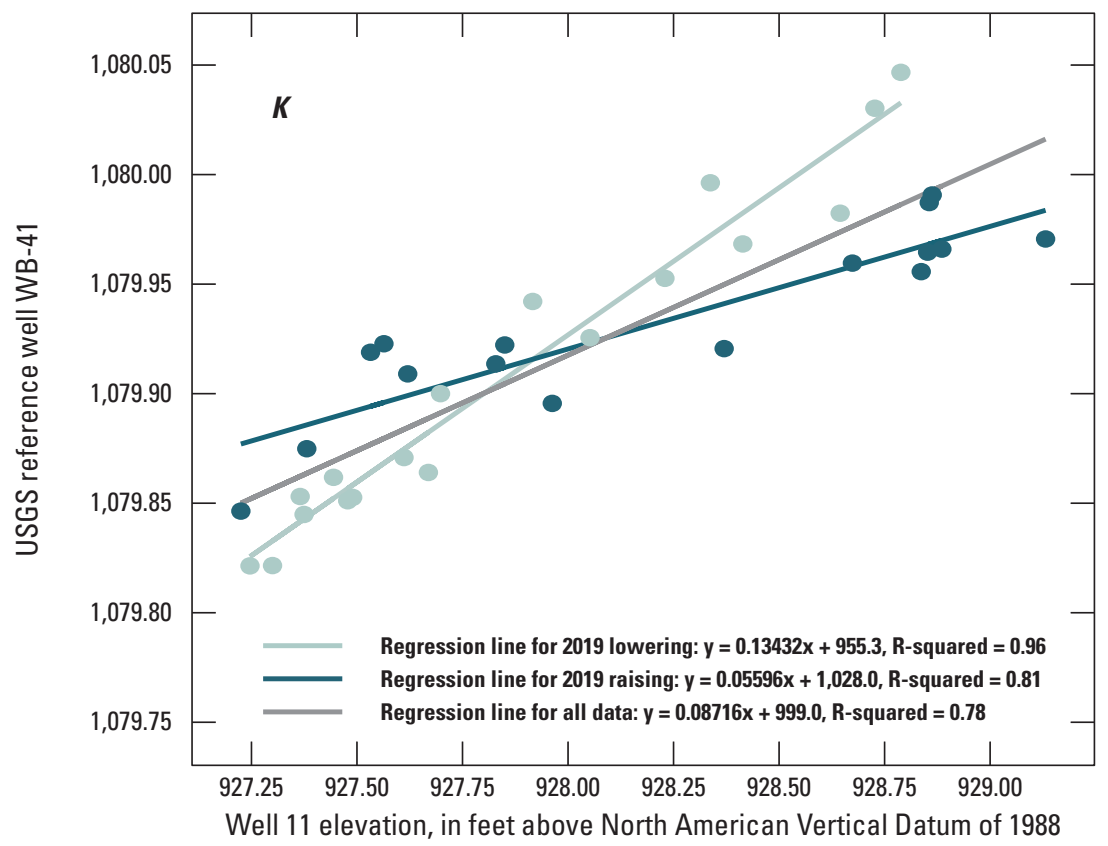

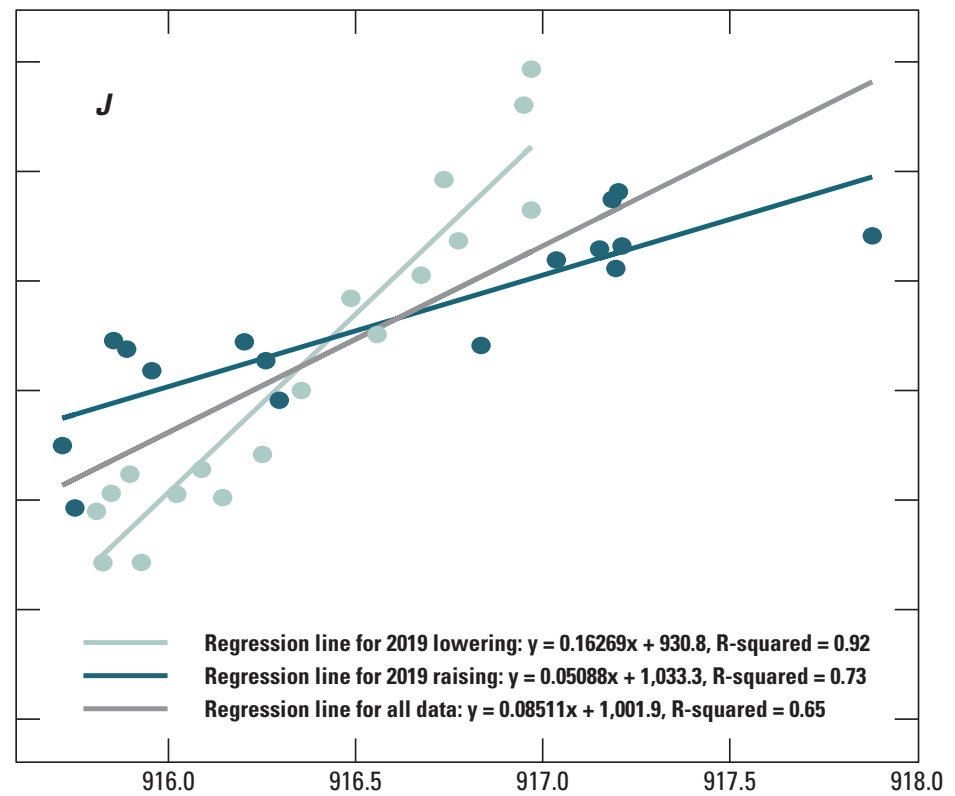

Well 10 elevation, in feet above North American Vertical Datum of 1988

\section{EXPLANATION}

[Elevation is in feet above North American Vertical Datum of 1988]

2019 falling

- 2019 rising 
A. 1:1 Plot of real well 5 and reference well WB-41 data

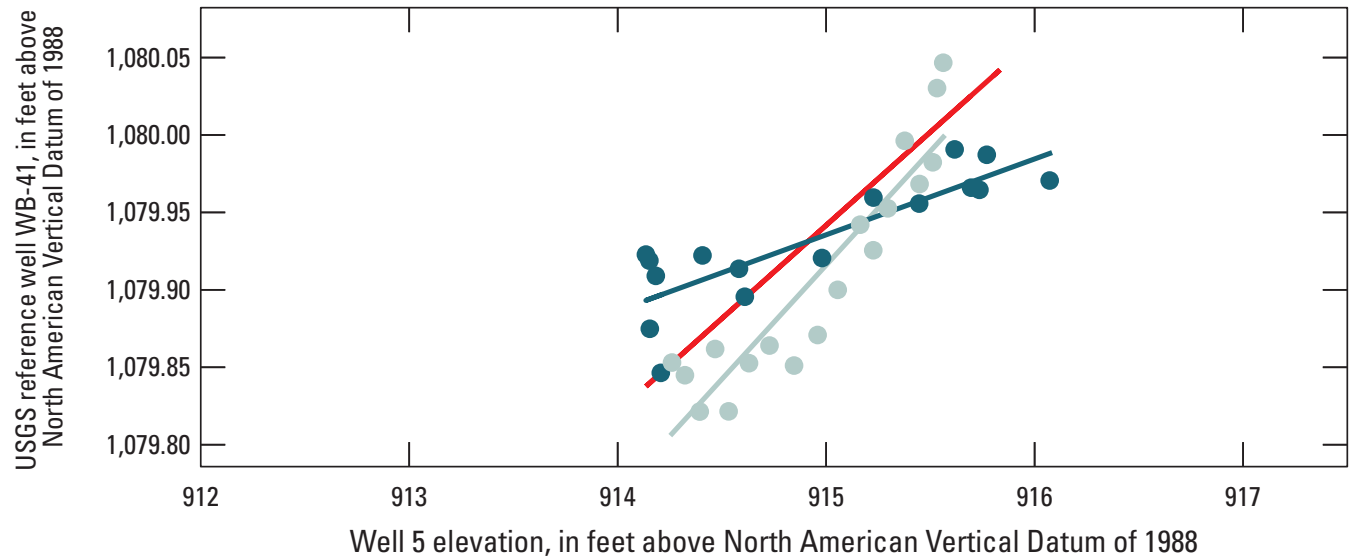

B. 1:1 Plot of synthetic well 5 and reference well WB-41 data

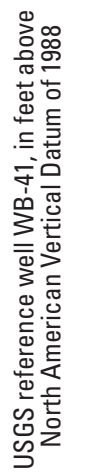

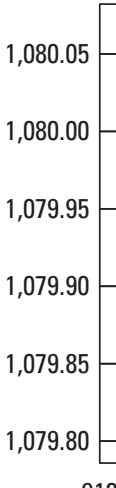

912

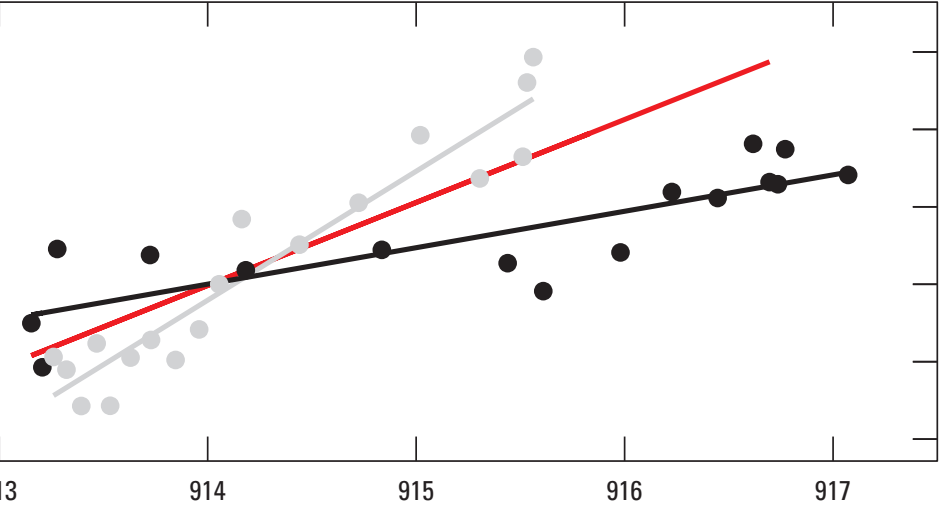

913

914

915

916

917

Synthetic well 5 elevation, in feet above North American Vertical Datum of 1988

EXPLANATION

Regression line for 2019

lowering: $\mathrm{y}=\mathbf{0 . 1 4 7 2 \mathrm { x } +}$

945.2, R-squared $=0.85$

Regression line for 2019

raising: $\mathrm{y}=0.04899 \mathrm{x}+$

$1,035.1$, R-squared $=0.73$

Regression line for all data: $y=0.12036 x+969.8$,

R-squared $=0.66$

2019 lowering - real data

- 2019 rising - real data

\section{Synthetic and real well 5 groundwater elevations - 3-day averages}

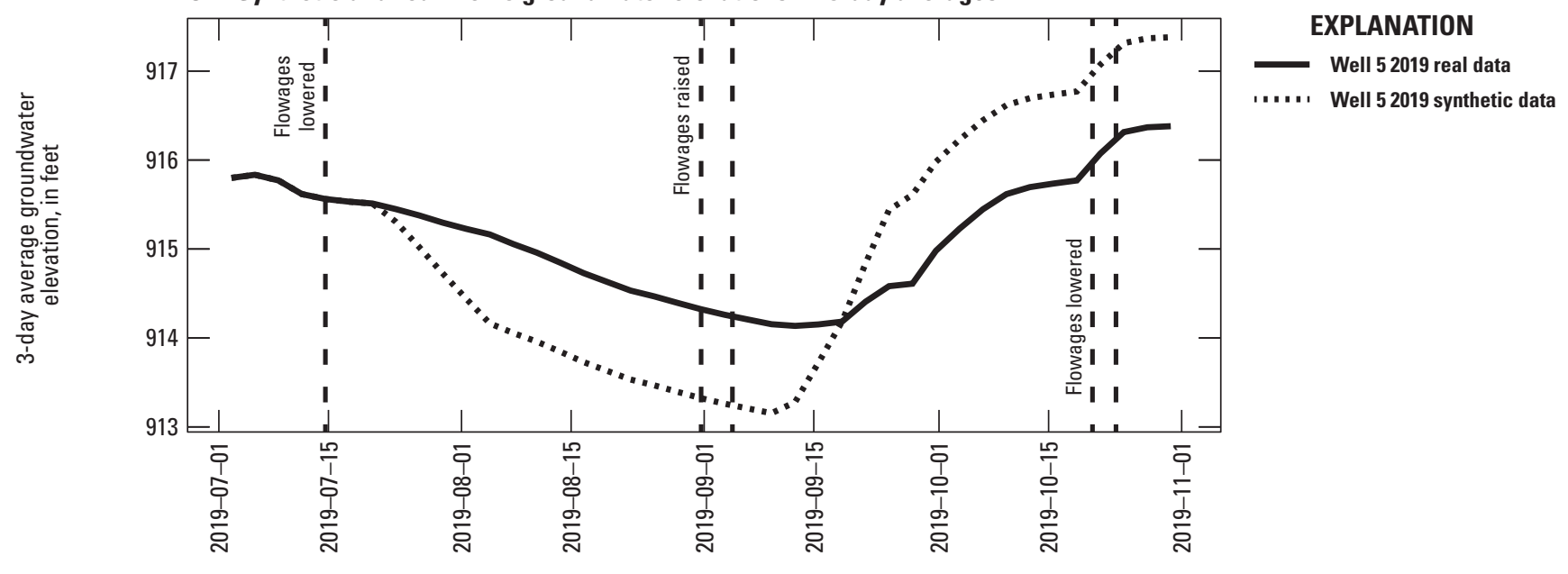

Date, in yyyy-mm-dd

Figure 7. Scatter plots of measured and synthetic study well 5 groundwater elevation and the simultaneous groundwater elevation in well WB-41, all resampled to 3-day means. The synthetic data represent a 1-foot drop in water levels during the initial flowage lowering period and followed by a 2-foot rise in water levels during the flowage raising period. This represents a 1-foot decline from prestudy water levels and a rise to 1-foot above prestudy levels. 
elevation changes are likely not substantial. Wells 1, 6, and 7 show noticeably different data patterns in the raising and lowering periods with a defined V-shaped gap between the trendlines from data for both periods. These three wells also show a much smaller R-squared value for the full dataset compared with the data from just the raising and lowering periods. This difference indicates that these wells may have experienced some additional change in groundwater elevations due to the flowage levels changing. Wells 1 and 7 are the wells in the flowage lakebeds and well 6 is $0.1 \mathrm{mi}$ east of the two flowages. Interestingly, wells 2 and 8, located a similar or shorter distance as well 6 , but west from the flowages did not show a pronounced gap in trendlines from the lowering and raising periods or large changes in the $\mathrm{R}$-squared values. The response in well 6, located east of the flowages, may be due to how water was moved on the Crex property to fill the Erickson and Dike 6 flowages.

The horizontal hydraulic gradient between each study well and study well 10 is presented in figure 8 with an identical vertical scale used for all plots. Figure 8 also has vertical dashed lines to show when the flowages were either raised or lowered. Wells 10 and 5 are assumed to be the least likely study wells to show responses to changes in the flowage elevations because they are farthest downgradient from the two flowages. A horizontal hydraulic gradient is calculated as the groundwater elevation in one well, minus the groundwater elevation in a second well, and divided by the horizontal distance between these two wells. The steeper the gradient, the more groundwater flow between two locations. A gradient calculated for two wells represents the average gradient between these wells but does not provide any information on the gradient at any particular intermediate segment because groundwater elevations can change nonuniformly between the wells. For example, figure 9 shows a schematic of hypothetical groundwater elevations between a "Well A" and "Well B." The horizontal hydraulic gradient is calculated as:

\section{horizontal hydraulic gradient $=$ \\ Groundwater elevation location 1 -Groundwater elevation location 2}

The average horizontal hydraulic gradient between Wells A and B in figure 9 is 0.01 foot per foot $(\mathrm{ft} / \mathrm{ft})$. However, the local gradient near Well A, where the water table is steep, is $0.04 \mathrm{ft} / \mathrm{ft}$ and the gradient near Well $\mathrm{B}$, where the water table is flatter, is $0.0017 \mathrm{ft} / \mathrm{ft}$. The average gradient between the two wells in this hypothetical example is calculated between the steep (larger) and the flatter (smaller) values.

Overall, the study wells showed small horizontal hydraulic gradient changes throughout the study period but were relatively stable. Wells $1,3,4$, and 7 showed the most variability in horizonal hydraulic gradient throughout the study period but it is difficult to relate the timing of those changes directly to periods of flowage raising and lowering. The other wells had relatively flat gradients throughout the study period.
Figures 10-12 show the actual departure from mean water levels (fig. 10), the cumulative departure from mean water levels (fig. 11), and the cumulative departure from mean water level for the same synthetic dataset used in figure 7 (fig. 12), as described in this section. The departure from the mean was calculated after the well data had been resampled to the mean of 3-day periods. A study-period mean groundwater elevation for each well was then calculated from the resampled 3-day period data. The departure from the mean is calculated as the difference from the mean for each resampled 3-day period data point. A departure from the mean above zero represents a period when the well groundwater elevation is above its average conditions during the study and a departure from the mean below zero represents a period when the groundwater elevation in the well was below the mean. Figure 10 shows the departure from the mean for all study wells, the regional well (WB-41), and the synthetic well 5 data, which represent a 1-ft lowering of well water levels followed by a 2-ft rise. In general, all the study wells showed greater changes in water levels than the regional well, likely because shallow wells such as the study wells typically respond much quicker to rain events and the drying periods whereas deeper wells like the regional well (well depth is $87 \mathrm{ft}$ below land surface) often show a more muted response. None of the study wells show mean departures as large as the synthetic well 5 data, which represent a 1-ft response above background to the raising and lowering. Well 1 data do deviate from the rest of the study wells and are most similar to the synthetic data.

Figure 11 shows the cumulative departure from the mean groundwater elevation for each of the study wells and regional well (WB-41). The cumulative departure is a continuous sum of the departure from mean values in figure 10 and amplifies any deviations in the departures. Before the study, the cumulative departure from this mean value was zero. By day 3, the cumulative departure is the 3-day mean groundwater elevation minus the study period mean. By day 6 , the cumulative departure is the day 3 departure from the mean plus or minus the day 6 departure. If the 3-day mean groundwater elevation in the well was above the study-period mean, that difference was added to the cumulative departure total. If the 3-day mean groundwater elevation in the well was below the mean, that difference was subtracted from the cumulative departure total. The cumulative departure total on a given date is equal to the cumulative sum of all differences from prior dates; for example, the cumulative departure value on September 15 is equal to the sum of all the differences for each 3-day period from late June (when the study started) to September 15 .

Figure 12 shows the cumulative departure from the mean for measured and synthetic well 5 data. The synthetic dataset is the same dataset used for the example scatter plot in figure 7 and represents a 1-ft drop in groundwater elevations at the well during the flowage lowering period (relative to the prestudy levels) followed by a 2 -ft rise in groundwater elevations during the raising period to bring water levels 1 - $\mathrm{ft}$ above 
A. Horizontal gradient between well 1 and well 10
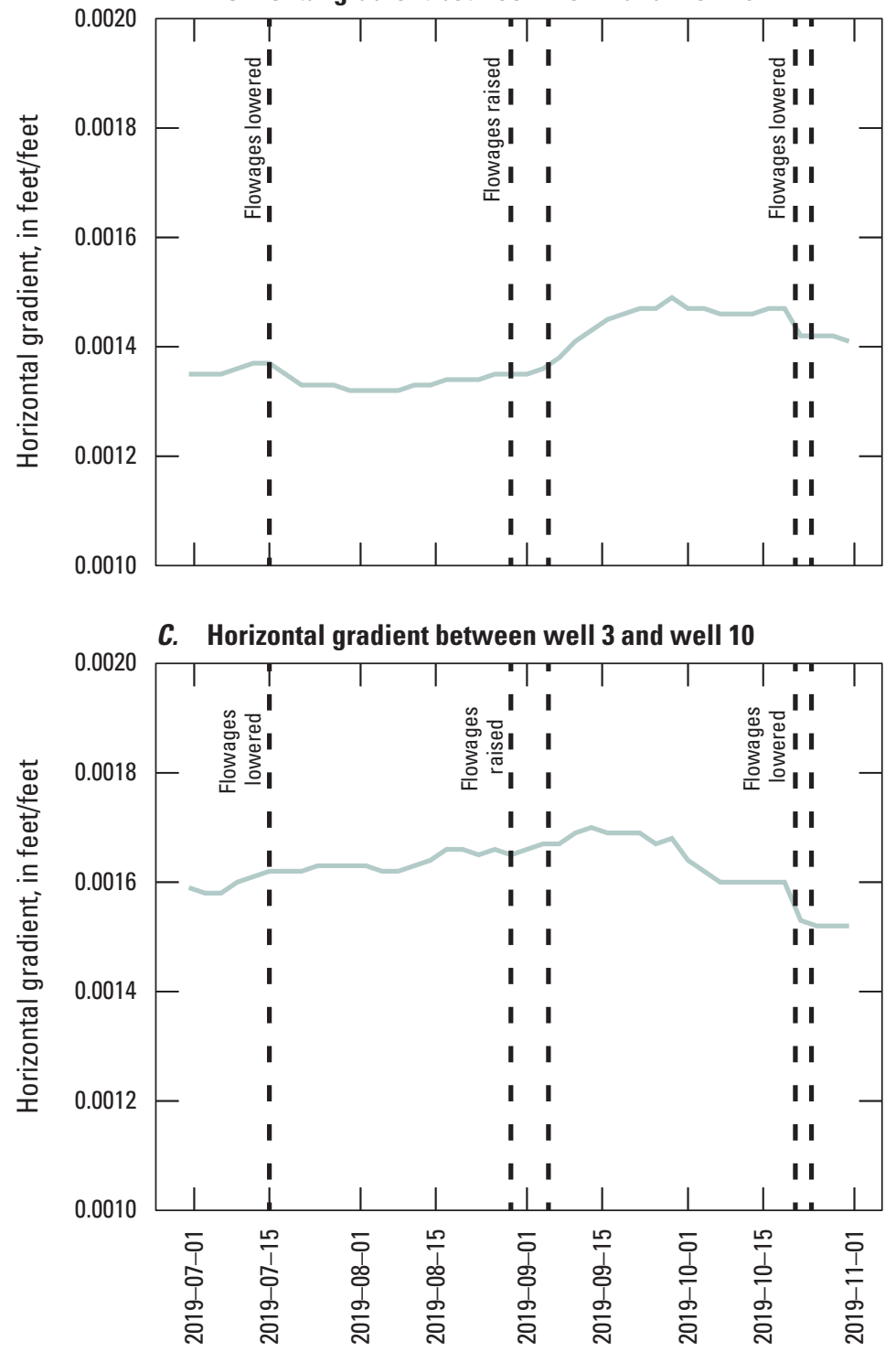

Date, in yyyy-mm-dd
B. Horizontal gradient between well 2 and well 10

$\vec{\infty}$

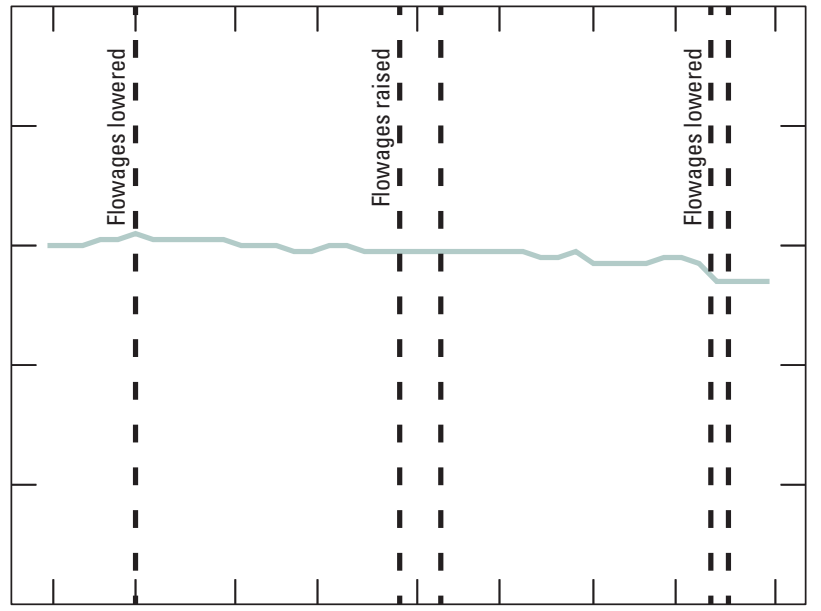

D. Horizontal gradient between well $\mathbf{4}$ and well $\mathbf{1 0}$

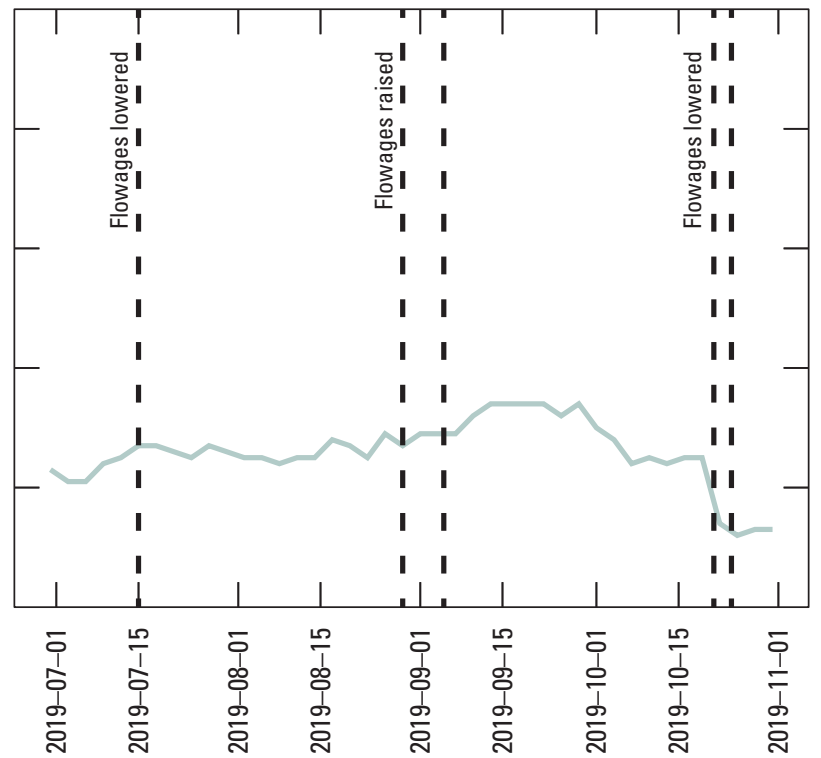

Date, in yyyy-mm-dd

Figure 8. Hydraulic gradients between each well and study well 10. Study well 10 is one of two study wells the farthest from the flowages and is least likely to show responses to changes in flowage water elevations. The gradients are calculated using the 3-day mean. Positive values indicate that the groundwater elevation in the plotted study well exceeds the elevation in study well 10. 
E. Horizontal gradient between well 5 and well 10

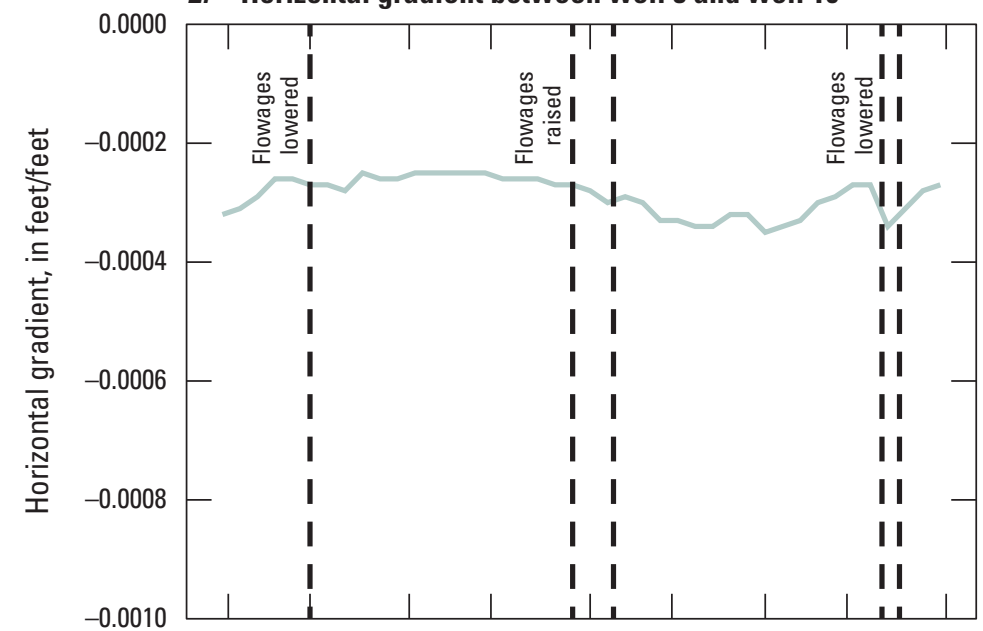

G. Horizontal gradient between well 7 and well 10

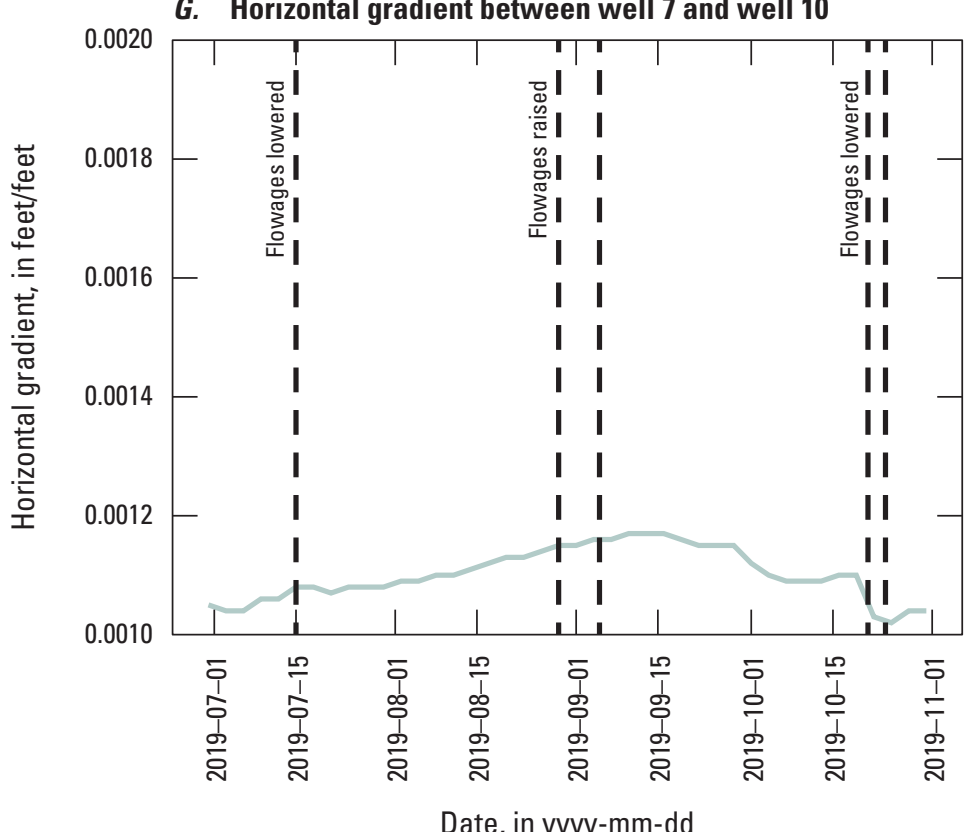

F. Horizontal gradient between well 6 and well 10

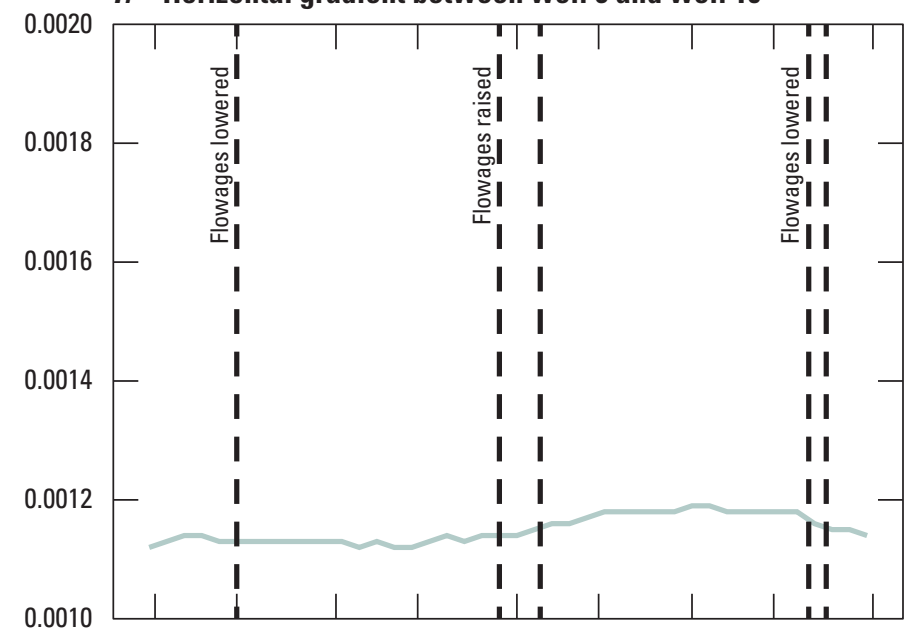

H. Horizontal gradient between well 8 and well 10

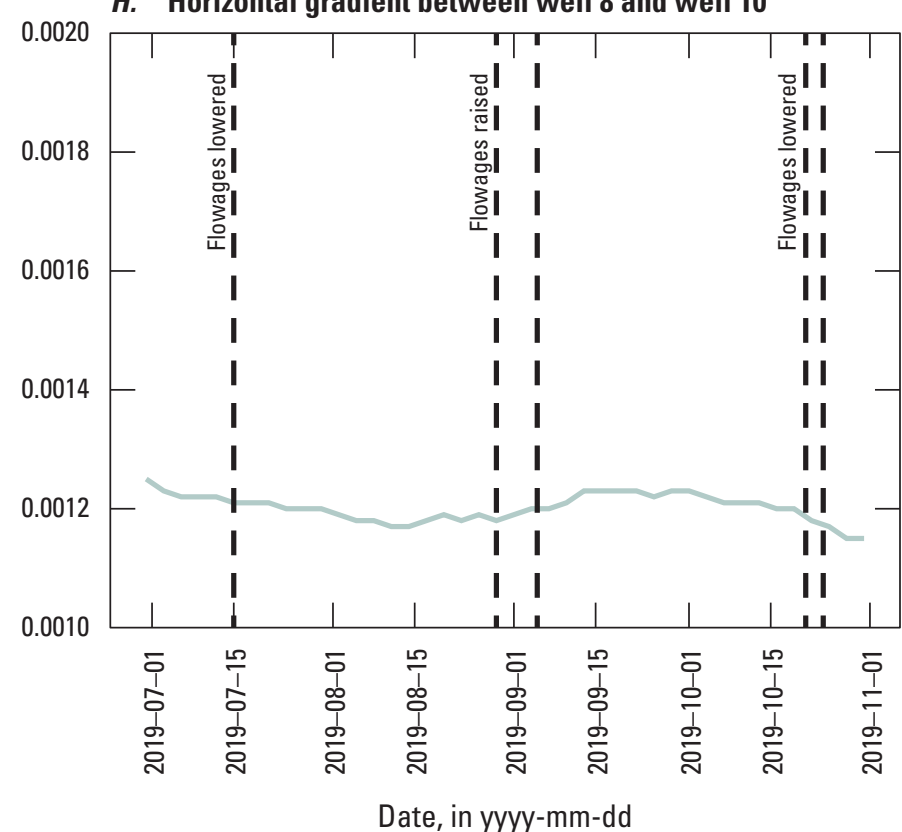

Figure 8. Hydraulic gradients between each well and study well 10. Study well 10 is one of two study wells the farthest from the flowages and is least likely to show responses to changes in flowage water elevations. The gradients are calculated using the 3 -day mean. Positive values indicate that the groundwater elevation in the plotted study well 


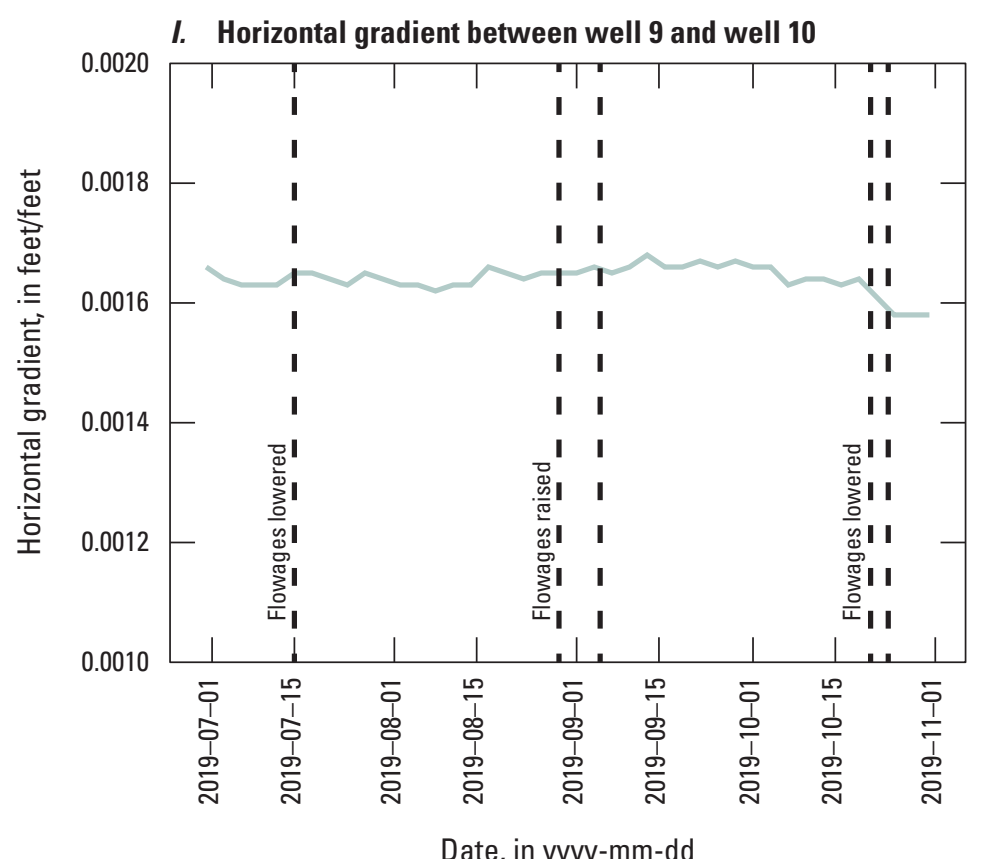

J. Horizontal gradient between well 11 and well 10

Figure 8. Hydraulic gradients between each well and study well 10. Study well 10 is one of two study wells the farthest from the flowages and is least likely to show responses to changes in flowage water elevations. The gradients are calculated using the 3-day mean. Positive values indicate that the groundwater elevation in the plotted study well exceeds the elevation in study well 10.- Continued 
EXPLANATION

[Figure is not to scale]

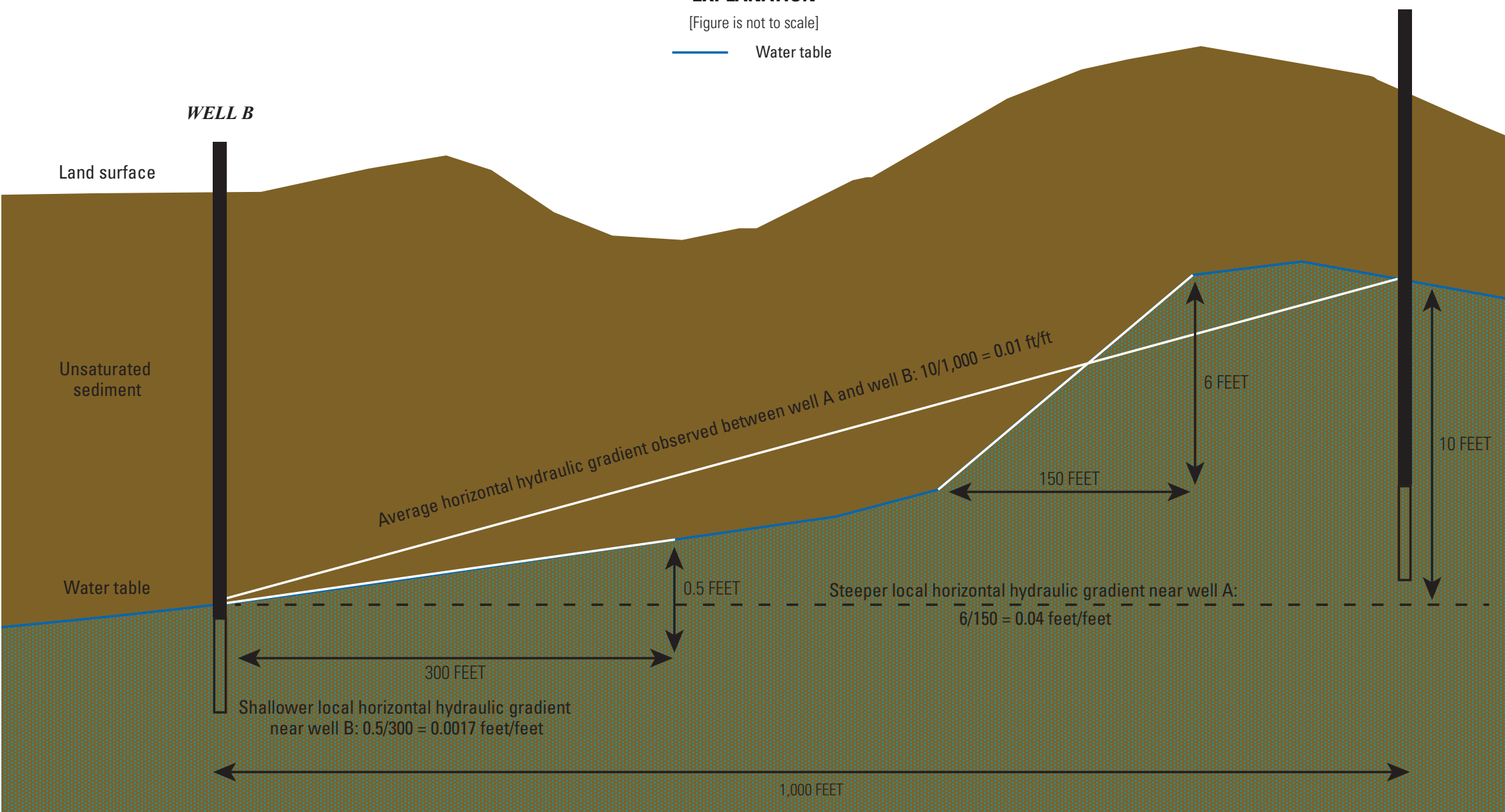

Figure 9. A schematic demonstrating the horizontal hydraulic gradient between two hypothetical wells, Well A and Well B. The horizontal hydraulic gradient calculated as average horizontal gradient between the two wells is 0.01 foot per foot $(\mathrm{ft} / \mathrm{ft})$. The local gradient near Well A is steeper $(0.04 \mathrm{ft} / \mathrm{ft})$ and the local gradient near Well B is flatter $(0.0017 \mathrm{ft} / \mathrm{ft})$. 


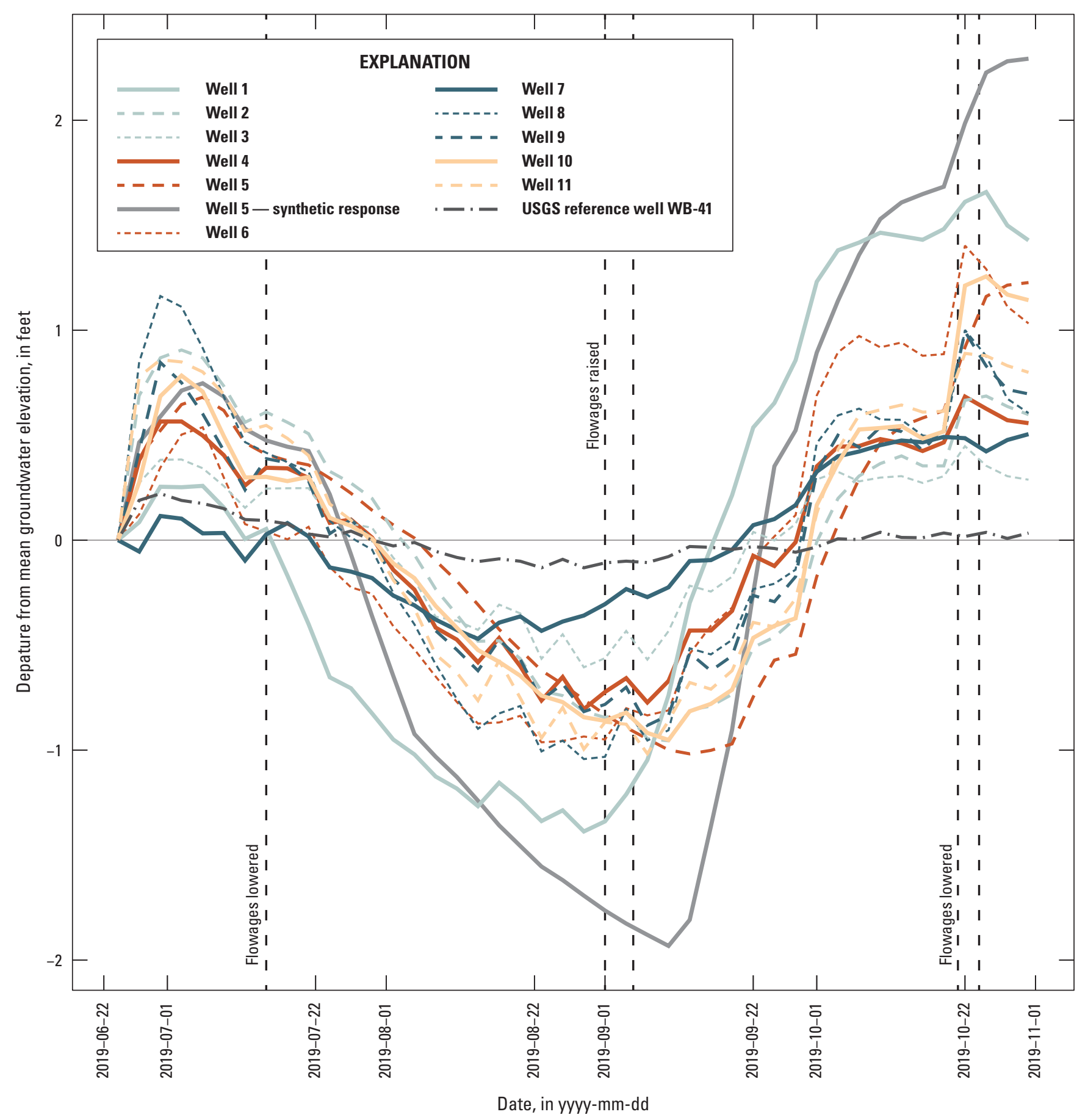

Figure 10. Departure from the mean groundwater elevation for the study period calculated with the 3-day mean. 


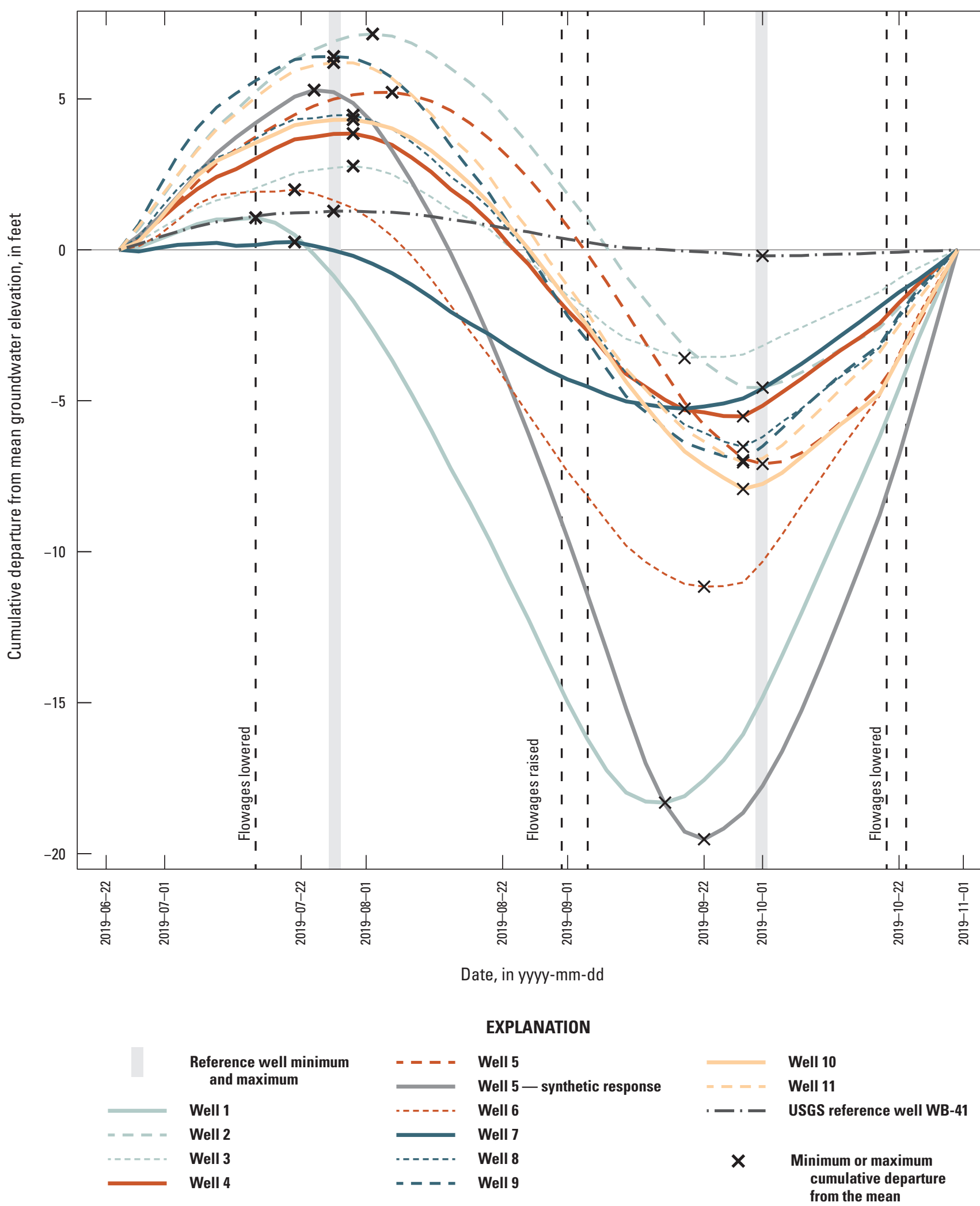

Figure 11. Cumulative departure from the mean groundwater elevation for the study period calculated with the 3-day mean. The minimum and maximum for each well are noted with an X. Grey rectangles indicate the maximum and minimum values for the regional well. 


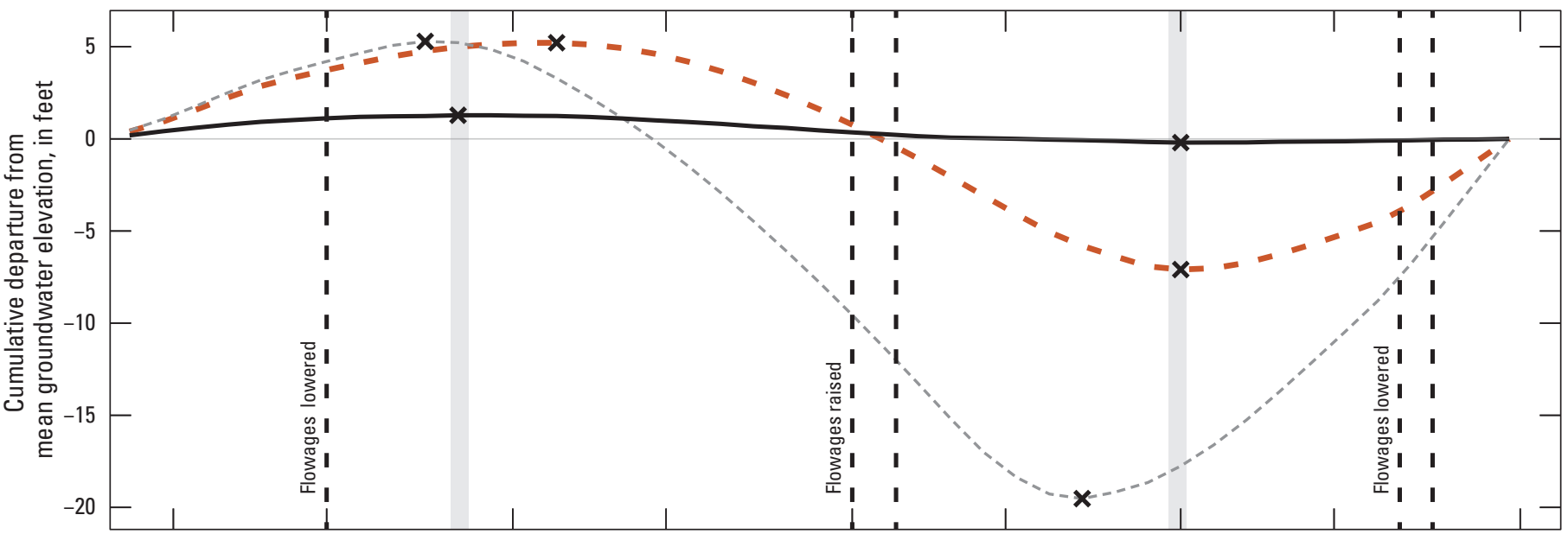

EXPLANATION

Reference well

minimum and

maximum

- $=$ - Well 5

USGS reference well WB-41

Well 5 - synthetic response

$\times \quad$ Minimum or maximum cumulative departure from the mean

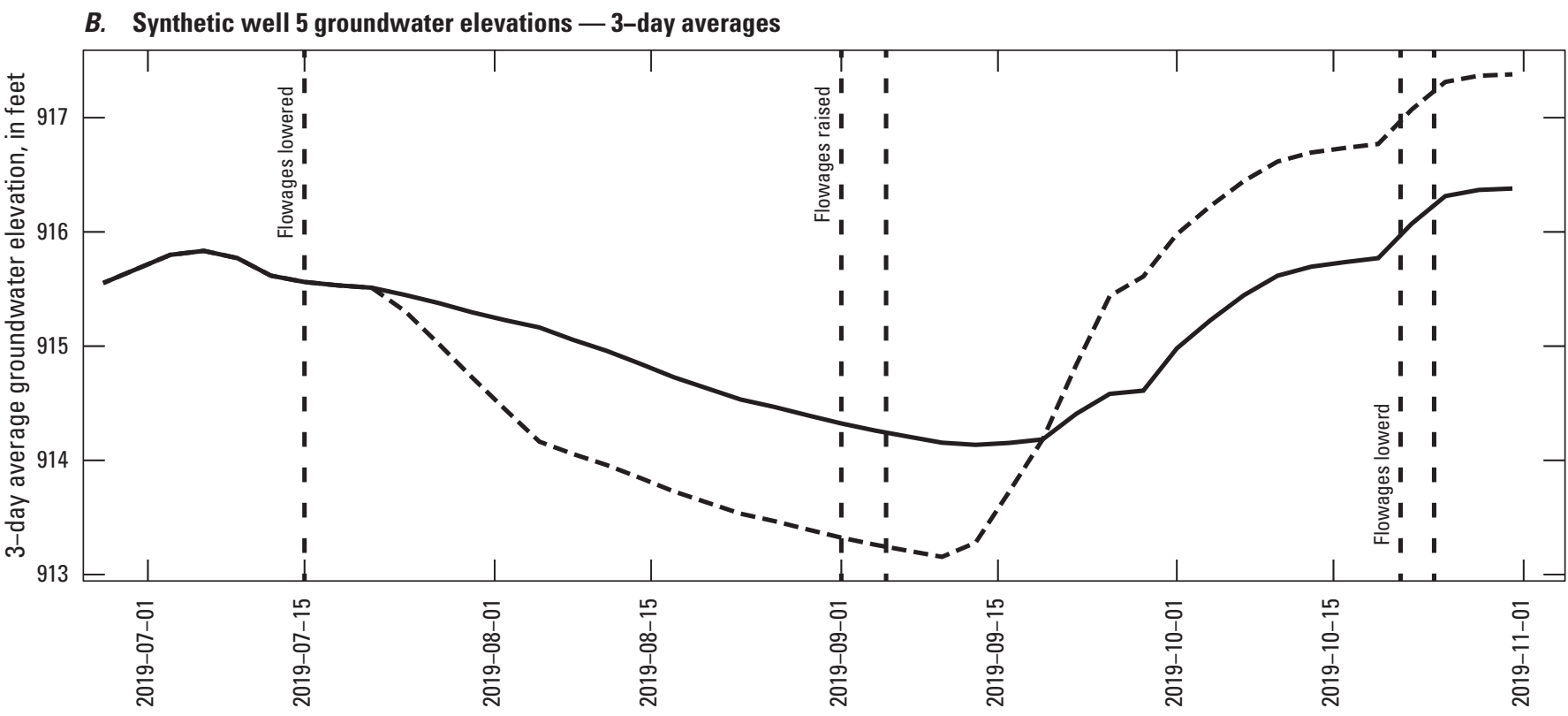

EXPLANATION

Well 52019 real data

Well 52019 synthetic

data

Date, in yyyy-mm-dd

Figure 12. Cumulative departure from the mean groundwater elevation for the study period calculated with the 3-day average groundwater elevations for measured well 5 data and a synthetic well 5 dataset that simulates a 1 -ft drop in water during the flowage lowering period followed by a 2 -ft rise in water levels during the flowage raising period. This synthetic change represents a 1 - $\mathrm{ft}$ decline from pre-study levels followed by raising water levels to $1 \mathrm{ft}$ above prestudy levels. The measured and synthetic time-series data of groundwater elevations are plotted for reference. 
the prestudy levels. Figure 12 represents how a response from the changing flowage levels may appear in the cumulative departure from the mean graph. In figure 12, the synthetic data have an earlier minimum and maximum and show a larger deviation in the magnitude of the minimum relative to the measured well data.

In general, the cumulative departures (fig. 11) show that study wells initially had groundwater elevations that were higher than their study period mean elevation (a positive cumulative departure term). Study well cumulative departures started to decline around August 1 and were generally below the study-period mean by mid-August. Around the end of September, when there was a lot of rain, the cumulative departure values started to increase, meaning the groundwater elevations in the study wells were again above their study-period mean value. Overall, most of the cumulative departures in study wells showed a similar pattern and timing of the minimum and maximum values. The regional well had smaller cumulative departure changes during this period, likely because it is a much deeper well (well depth is $87 \mathrm{ft}$ below land surface) than the study wells. Wells 1 and 6 had the most significant differences in the magnitude of maximum and minimum departure values with a maximum peak occurring before the other study wells. Wells 1 (in the Dike 6 flowage lakebed) and 6 (east of the flowages) had higher peak cumulative departure values and lower minimum cumulative departure values than most of the study wells. Well 7 (in the Erickson flowage lakebed) had a more muted curve but did show an earlier maximum peak than other study wells. Well 7 may have experienced some effects from the flowages changes but also generally experienced a more constant groundwater elevation than the other study wells.

One potential limitation of this study is that the period of data collection was only 3 months, approximately 1.5 months for the raising period and 1.5 months for the lowering period. It is possible that during a longer period, the effects of flowage water-level changes could propagate out farther than those observed in this study. The length of study was selected to provide results in a reasonable time period and to capture the typical length of time over which flowage water-level changes occur; in a typical year water is released in the spring, then raised and held higher during the late growing season, and then stabilized just before winter. A possible follow-on to this study would be to keep a sentry well along the western boundary of Crex near the flowages for longer-term data collection during typical annual flowage management regimes. During this study, a long-term USGS monitoring well (site no. 454953092432502) was added to the statewide monitoring well network next to study well 10. The data collected at this USGS monitoring well will provide information on the regional groundwater flow levels near Crex and context for when the regional groundwater elevations are higher than average. The data from this well may be useful if future groundwater flooding occurs in the region.

\section{Summary}

This study successfully collected groundwater elevations in 11 study wells inside and to the west of the Crex Meadows Wildlife Area (Crex) during a 3-month period in 2019. The Dike 6 and Erickson flowage water elevations were lowered and then raised during the study period to evaluate the degree to which flowage water levels affect local groundwater levels. Continuous groundwater elevation data collection from a 12th location (well 12) failed. The groundwater elevation trends in these study wells were compared with trends at regional well WB-41 to determine if changing the flowage elevations had a noticeable response in the study wells west of Crex. This analysis was performed by examining general groundwater elevation trends in the study wells compared to well WB-41; using a scatter plot to compare the relation between the study wells and WB-41 well water levels during the flowage raising and lowering periods; assessing a time-series of horizontal hydraulic gradient data during the study period; and analyzing the cumulative departure from the mean for each well.

Overall, the regional groundwater levels trended downward before and during the flowage lowering period and then upward during the flowage raising period. This trend was observed in the regional well WB-41, and in all the study wells near and far from the flowages. Because study wells mirror the ambient regional conditions in WB-41 (not affected by flowages) it seems that the dominant driver of the local groundwater system is the same as the regional system-precipitation patterns. The scatter plot data showed different patterns in data collected during the raising and lowering periods for wells 1,6 , and 7 and the other study well data plotted together for both periods. The cumulative departure from the mean data also showed the biggest outliers in the magnitude and timing of the cumulative departure peaks for wells 1 , 6 , and 7 . Together, the scatter plot and cumulative departure from the mean analysis showed that in addition to regional trends, wells 1, 6, and 7 were likely affected by additional stresses like the changes in the flowage water levels. These deviations were analyzed in the context of a synthetic well response of a 1-foot (ft) drop below prestudy levels followed by a 2 -ft rise to $1 \mathrm{ft}$ above prestudy water levels. None of the study wells (except maybe well 1) showed responses that were similar to the synthetic data and most plotted in a similar manner to all the other wells for all the data analysis techniques. This evidence indicates that the detectable responses in local groundwater levels due to changing flowage water levels is of minimal spatial extent and likely limited to areas very close to the flowages within the time periods studied. There were no detectable responses observed in wells outside of the Crex property. This finding is consistent with the other literature studies showing that the effects on groundwater levels downgradient of a water control feature in low topographic relief areas with fine sediment may have limited extent. 
During this study, a long-term USGS monitoring well (site no. 454953092432502) was added to the statewide monitoring well network and is located near Crex. The data collected at this USGS well will provide information on the regional groundwater flow levels near Crex and context for when the regional groundwater elevations are higher than average. The data from this well may be useful if future groundwater flooding occurs in the region.

\section{References Cited}

Berthelote, A.R., 2013, Forecasting groundwater responses to dam removal: Missoula, University of Montana, Master's thesis, The University of Montana, 77 p., accessed January 8, 2020 at https://scholarworks.umt.edu/cgi/ viewcontent.cgi article $=2421 \&$ context $=$ etd

Cunningham, W.L., and Schalk, C.W., comps., 2011, Groundwater technical procedures of the U.S. Geological Survey: U.S. Geological Survey Techniques and Methods 1-A1, 151 p. (available only online at https://pubs .usgs.gov/tm/1a1/)

McKay, L., Bondelid, T., Dewald, T., Johnston, J., Moore, R., and Rea, A., 2012, National Hydrography Dataset Plus, version 2-User guide: U.S. Environmental Protection Agency, accessed July 18, 2018, at http://www.horizon-systems.com/ nhdplus/NHDPlusV2_data.php

Mioduszewski, W., 2011, Water reservoirs, effects on soil and groundwater in Gliński J., Horabik J., Lipiec J. (eds) Encyclopedia of agrophysics: Encyclopedia of earth sciences series. Dordrecht, Springer, p. 973-975, accessed January 8, 2020 at https://link.springer.com/ referenceworkentry/10.1007\%2F978-90-481-3585-1_254

Muldoon, M.A., Madison, F.W., and Johnson, M.D., 1990, Soils, geologic, and hydrogeologic influences on lake water quality in northwestern Wisconsin: Wisconsin Geological and Natural History Open-File Report 90-1, 74 p., accessed January 8, 2020, at https://wgnhs.wisc.edu/pubs/000767/

National Oceanic and Atmospheric Administration [NOAA], 2020, Daily summaries station details for GRANTSBURG 0.6 SSW, WI US, climate dataset, accessed January 8, 2020, at https:/www.ncdc.noaa.gov/cdo-web/datasets/GHCND/ stations/GHCND:US1WIBT0001/detail

Patterson, G.L., 1990, Ground-water levels and quality at Crex Meadows Wildlife Area, Burnett County, Wisconsin: U.S. Geological Survey Water-Resources Investigations Report 89-4129, 19 p.
Richie, J., 2018, West Marshland residents voice concerns about high water levels in Crex Meadows: Burnett County (Wisconsin) Sentinel, August 23, 2018, accessed September 13, 2018 at http://www.burnettcountysen tinel.com/news/west-marshland-residents-voice-concernsabout-high-water-levels-in/article_4b28dd84-a635-11e8a729-b3d86578aa55.html

U.S. Geological Survey, 2019, USGS water data for the Nation: U.S. Geological Survey National Water Information System database, accessed January 8, 2020, at https://doi.org/10.5066/F7P55KJN.

Vogl, R.J., 1964, Vegetational history of Crex Meadows, a prairie savanna in northwestern Wisconsin: American Midland Naturalist, v. 72, no. 1, p. 157-175, https://www. jstor.org/stable/2423220?seq=1\#metadata_info_tab contents, accessed January 8, 2020.

Westbrook, C.J., Cooper, D.J., and Baker, B.W., 2006, Beaver dams and overbank floods influence groundwater-surface water interactions of a Rocky Mountain riparian area: Water Resources Research, v. 42, no. 6, 12 p., accessed January 8, 2020, https://agupubs.onlinelibrary.wiley.com/doi/full/ 10.1029/2005WR004560\#wrcr10611-fig-0008

Wisconsin Department of Natural Resources [WDNR], 2002, Wisconsin Wetlands Inventory data - Burnett County, accessed September 18, 2018, at https://www.fws.gov/ wetlands/Data/State-Downloads.html

Wisconsin Department of Natural Resources [WDNR], 2018a, Crex Meadows Wildlife Area, accessed September 19, 2018, at https://dnr.wi.gov/topic/lands/wildlifeareas/ crex.html

Wisconsin Department of Natural Resources [WDNR], 2018b, DNR managed properties dataset, Bureau of Facilities and Lands - Real Estate Section, accessed September 14, 2018, at https://data-wi-dnr.opendata.arcgis.com/datasets/040 0005343db41bd850043f9f5f9176b_0

Wisconsin Department of Natural Resources [WNDR], 2019, Groundwater levels and aquifer response, accessed January 1, 2020, at https://dnr.wi.gov/topic/WaterUse/ gwLevels.html

Woo, M., and Waddington, J.M., 1990, Effects of beaver dams on subarctic wetland hydrology: Arctic, v. 43, no. 3, p. 223-230, https://journalhosting.ucalgary.ca/index.php/ arctic/article/view/64669/48583, accessed January 8, 2020. 


\section{Appendix 1. Flowage Elevation Data}

Flowage elevation were provided by the WDNR and are summarized in tables A1 and A2. (K. Anderson, WDNR Natural Resource Property Supervisor and A. Hawley, Wildlife Technician-Advanced, written commun., 2019).

Table 1.1. Dike 6 flowage elevations.

[NAVD 88, North American Vertical Datum of 1988; m/d/yyyy, date in month, day, year; <, below the bottom of the staff gage]

\begin{tabular}{|c|c|c|}
\hline Date & Flowage elevation, in feet above NAVD88 & Comments \\
\hline $6 / 19 / 2018$ & 935.28 & None \\
\hline $6 / 26 / 2018$ & 935.65 & None \\
\hline $6 / 27 / 2018$ & 935.68 & None \\
\hline $7 / 2 / 2018$ & 935.68 & None \\
\hline $7 / 3 / 2018$ & 935.66 & None \\
\hline $7 / 6 / 2018$ & 935.68 & None \\
\hline 7/9/2018 & 935.58 & None \\
\hline $7 / 12 / 2018$ & 935.78 & None \\
\hline $7 / 13 / 2018$ & 935.82 & None \\
\hline 8/8/2018 & 935.5 & None \\
\hline $8 / 14 / 2018$ & 935.48 & None \\
\hline $9 / 14 / 2018$ & 935.08 & None \\
\hline $10 / 26 / 2018$ & 935.4 & None \\
\hline $11 / 5 / 2018$ & 935.25 & None \\
\hline $12 / 3 / 2018$ & 935.05 & Frozen \\
\hline $3 / 18 / 2019$ & 935.05 & Frozen \\
\hline $3 / 21 / 2019$ & 935.05 & Frozen \\
\hline $3 / 25 / 2019$ & 935.05 & Frozen \\
\hline $3 / 28 / 2019$ & 935.62 & None \\
\hline $4 / 1 / 2019$ & 935.3 & None \\
\hline $4 / 3 / 2019$ & 935.22 & None \\
\hline 4/8/2019 & 935.28 & None \\
\hline 4/10/2019 & 935.26 & None \\
\hline $4 / 15 / 2019$ & 935.3 & None \\
\hline $4 / 18 / 2019$ & 935.48 & None \\
\hline $4 / 19 / 2019$ & 935.56 & None \\
\hline $4 / 29 / 2019$ & 935.49 & None \\
\hline $5 / 5 / 2019$ & 935.43 & None \\
\hline $5 / 18 / 2019$ & 935.7 & None \\
\hline $5 / 20 / 2019$ & 935.98 & None \\
\hline $5 / 22 / 2019$ & 936.08 & None \\
\hline $5 / 23 / 2019$ & 936.1 & None \\
\hline $5 / 24 / 2019$ & 936.08 & None \\
\hline
\end{tabular}


28 Assessment of Groundwater Trends near Crex Meadows, Wisconsin

Table 1.1. Dike 6 flowage elevations. - Continued

[NAVD 88, North American Vertical Datum of 1988; m/d/yyyy, date in month, day, year; <, below the bottom of the staff gage]

\begin{tabular}{|c|c|c|}
\hline Date & Flowage elevation, in feet above NAVD88 & Comments \\
\hline $5 / 25 / 2019$ & 935.96 & None \\
\hline $5 / 29 / 2019$ & 935.68 & None \\
\hline $5 / 31 / 2019$ & 935.58 & None \\
\hline $6 / 3 / 2019$ & 935.38 & None \\
\hline $6 / 4 / 2019$ & 935.26 & None \\
\hline $6 / 5 / 2019$ & 935.24 & None \\
\hline $6 / 7 / 2019$ & 935.19 & None \\
\hline $6 / 10 / 2019$ & 935.1 & None \\
\hline $6 / 11 / 2019$ & 935.08 & None \\
\hline $6 / 12 / 2019$ & 935.13 & None \\
\hline $6 / 19 / 2019$ & 935 & None \\
\hline $6 / 26 / 2019$ & 935.04 & None \\
\hline $6 / 27 / 2019$ & 935.05 & None \\
\hline $6 / 28 / 2019$ & 935.1 & None \\
\hline $6 / 30 / 2019$ & 935.07 & None \\
\hline $7 / 1 / 2019$ & 935.1 & None \\
\hline 7/8/2019 & 935.18 & None \\
\hline $7 / 9 / 2019$ & 935.09 & None \\
\hline $7 / 10 / 2019$ & 935.04 & None \\
\hline $7 / 12 / 2019$ & 935 & None \\
\hline $7 / 15 / 2019$ & 934.98 & None \\
\hline $7 / 16 / 2019$ & 934.68 & None \\
\hline $7 / 17 / 2019$ & 934.44 & None \\
\hline $7 / 18 / 2019$ & 934.24 & None \\
\hline $7 / 19 / 2019$ & 934.1 & None \\
\hline $7 / 22 / 2019$ & 933.8 & None \\
\hline $7 / 24 / 2019$ & 933.58 & None \\
\hline $7 / 25 / 2019$ & 933.48 & None \\
\hline $7 / 26 / 2019$ & 933.38 & None \\
\hline $7 / 28 / 2019$ & $<933.34$ & None \\
\hline $7 / 29 / 2019$ & 933.36 & None \\
\hline $7 / 30 / 2019$ & 933.3 & Estimated \\
\hline $7 / 31 / 2019$ & 933.24 & Estimated \\
\hline $8 / 1 / 2019$ & 933.24 & Estimated \\
\hline $8 / 5 / 2019$ & $<933.2$ & None \\
\hline 8/6/2019 & $<933.2$ & None \\
\hline 8/7/2019 & $<933.2$ & None \\
\hline $9 / 3 / 2019$ & $<933.2$ & None \\
\hline $9 / 4 / 2019$ & $<933.2$ & None \\
\hline $9 / 5 / 2019$ & 933.48 & None \\
\hline $9 / 6 / 2019$ & 933.76 & None \\
\hline 9/7/2019 & 933.9 & None \\
\hline
\end{tabular}


Table 1.1. Dike 6 flowage elevations.-Continued

[NAVD 88, North American Vertical Datum of 1988; m/d/yyyy, date in month, day, year; <, below the bottom of the staff gage]

\begin{tabular}{|c|c|c|}
\hline Date & Flowage elevation, in feet above NAVD88 & Comments \\
\hline $9 / 8 / 2019$ & 934 & None \\
\hline 9/9/2019 & 934.13 & None \\
\hline $9 / 10 / 2019$ & 934.29 & None \\
\hline $9 / 11 / 2019$ & 934.47 & None \\
\hline $9 / 12 / 2019$ & 934.6 & None \\
\hline $9 / 13 / 2019$ & 934.8 & None \\
\hline $9 / 14 / 2019$ & 935 & None \\
\hline $9 / 15 / 2019$ & 935.24 & None \\
\hline $9 / 16 / 2019$ & 935.36 & None \\
\hline $9 / 17 / 2019$ & 935.5 & None \\
\hline $9 / 18 / 2019$ & 935.64 & None \\
\hline $9 / 19 / 2019$ & 935.82 & None \\
\hline $9 / 20 / 2019$ & 935.88 & None \\
\hline $9 / 21 / 2019$ & 935.95 & None \\
\hline $9 / 22 / 2019$ & 936.18 & None \\
\hline $9 / 23 / 2019$ & 936.26 & None \\
\hline $9 / 24 / 2019$ & 936.3 & None \\
\hline $9 / 25 / 2019$ & 936.36 & None \\
\hline $9 / 26 / 2019$ & 936.4 & None \\
\hline $9 / 27 / 2019$ & 936.45 & None \\
\hline $9 / 29 / 2019$ & 936.52 & None \\
\hline $9 / 30 / 2019$ & 936.78 & None \\
\hline $10 / 1 / 2019$ & 937.94 & None \\
\hline $10 / 2 / 2019$ & 937 & None \\
\hline $10 / 3 / 2019$ & 937.07 & None \\
\hline $10 / 4 / 2019$ & 937.08 & None \\
\hline $10 / 6 / 2019$ & 937.18 & None \\
\hline $10 / 7 / 2019$ & 937.2 & None \\
\hline $10 / 8 / 2019$ & 937.14 & None \\
\hline $10 / 9 / 2019$ & 937.16 & None \\
\hline $10 / 10 / 2019$ & 937.18 & None \\
\hline $10 / 11 / 2019$ & 937.22 & None \\
\hline $10 / 14 / 2019$ & 937.22 & None \\
\hline $10 / 15 / 2019$ & 937.18 & None \\
\hline $10 / 16 / 2019$ & 937.2 & None \\
\hline $10 / 17 / 2019$ & 937.19 & None \\
\hline $10 / 18 / 2019$ & 937.19 & None \\
\hline $10 / 19 / 2019$ & 937.2 & None \\
\hline $10 / 21 / 2019$ & 937.36 & None \\
\hline $10 / 22 / 2019$ & 937.42 & None \\
\hline $10 / 23 / 2019$ & 937.42 & None \\
\hline $10 / 24 / 2019$ & 937.41 & None \\
\hline
\end{tabular}


30 Assessment of Groundwater Trends near Crex Meadows, Wisconsin

Table 1.1. Dike 6 flowage elevations.-Continued

[NAVD 88, North American Vertical Datum of 1988; m/d/yyyy, date in month, day, year; <, below the bottom of the staff gage]

\begin{tabular}{lcl}
\hline \multicolumn{1}{c}{ Date } & Flowage elevation, in feet above NAVD88 & \multicolumn{1}{c}{ Comments } \\
\hline $10 / 25 / 2019$ & 937.22 & None \\
$10 / 26 / 2019$ & 937.19 & None \\
$10 / 28 / 2019$ & 937.13 & None \\
$10 / 29 / 2019$ & 937.02 & None \\
$10 / 30 / 2019$ & 936.92 & None \\
$10 / 31 / 2019$ & 936.87 & None \\
$11 / 4 / 2019$ & 936.36 & None \\
$11 / 8 / 2019$ & 935.98 & None \\
$11 / 11 / 2019$ & 935.78 & None \\
$11 / 12 / 2019$ & 935.7 & None \\
\hline
\end{tabular}

Table 1.2. Erickson flowage elevations.

[NAVD 88, North American Vertical Datum of 1988; m/d/yyyy, date in month, day, year; <, below the bottom of the staff gage]

\begin{tabular}{|c|c|c|}
\hline Date & Flowage elevation, in feet above NAVD88 & Comments \\
\hline 8/9/2018 & $<928.30$ & None \\
\hline $5 / 5 / 2019$ & 929.2 & None \\
\hline $5 / 20 / 2019$ & 929.76 & None \\
\hline $5 / 22 / 2019$ & 930.1 & None \\
\hline $5 / 23 / 2019$ & 930.28 & None \\
\hline $5 / 24 / 2019$ & 930.32 & None \\
\hline $5 / 25 / 2019$ & 930.28 & None \\
\hline $5 / 29 / 2019$ & 929.86 & None \\
\hline $5 / 31 / 2019$ & 929.19 & None \\
\hline $6 / 2 / 2019$ & 928.9 & None \\
\hline $6 / 7 / 2019$ & 929.42 & None \\
\hline $6 / 10 / 2019$ & 929.3 & None \\
\hline $6 / 11 / 2019$ & 929.29 & None \\
\hline $6 / 12 / 2019$ & 929.35 & None \\
\hline $6 / 19 / 2019$ & 929.18 & None \\
\hline 7/1/2019 & 929.24 & None \\
\hline $7 / 15 / 2019$ & 928.92 & None \\
\hline $7 / 16 / 2019$ & 928.4 & None \\
\hline $7 / 17 / 2019$ & 928.64 & None \\
\hline $7 / 19 / 2019$ & 928.48 & None \\
\hline $7 / 22 / 2019$ & 928.28 & None \\
\hline $7 / 23 / 2019$ & 927.88 & None \\
\hline $7 / 24 / 2019$ & 927.28 & None \\
\hline $7 / 25 / 2019$ & 927.69 & None \\
\hline $7 / 26 / 2019$ & 927.61 & None \\
\hline $7 / 28 / 2019$ & 927.52 & None \\
\hline
\end{tabular}


Table 1.2. Erickson flowage elevations.-Continued

[NAVD 88, North American Vertical Datum of 1988; m/d/yyyy, date in month, day, year; <, below the bottom of the staff gage]

\begin{tabular}{|c|c|c|}
\hline Date & Flowage elevation, in feet above NAVD88 & Comments \\
\hline $7 / 29 / 2019$ & 927.66 & None \\
\hline $7 / 30 / 2019$ & 927.58 & None \\
\hline $7 / 31 / 2019$ & 927.56 & None \\
\hline $8 / 1 / 2019$ & 927.5 & None \\
\hline $8 / 5 / 2019$ & 927.44 & None \\
\hline 8/6/2019 & 927.34 & None \\
\hline $8 / 8 / 2019$ & 927.34 & None \\
\hline 8/9/2019 & 927.42 & None \\
\hline $8 / 12 / 2019$ & 927.18 & None \\
\hline $8 / 16 / 2019$ & 927.1 & None \\
\hline $8 / 29 / 2019$ & 927.21 & None \\
\hline $8 / 31 / 2019$ & 929.02 & None \\
\hline $9 / 10 / 2019$ & 929.1 & None \\
\hline $9 / 2 / 2019$ & 929.24 & None \\
\hline 9/3/2019 & 929.44 & None \\
\hline 9/5/2019 & 929.52 & None \\
\hline 9/6/2019 & 929.56 & None \\
\hline 9/7/2019 & 929.56 & None \\
\hline 9/8/2019 & 929.56 & None \\
\hline 9/9/2019 & 929.56 & None \\
\hline 9/10/2019 & 929.58 & None \\
\hline $9 / 11 / 2019$ & 929.61 & None \\
\hline $9 / 12 / 2019$ & 929.66 & None \\
\hline $9 / 13 / 2019$ & 929.76 & None \\
\hline $9 / 14 / 2019$ & 929.79 & None \\
\hline $9 / 15 / 2019$ & 929.83 & None \\
\hline 9/16/2019 & 929.84 & None \\
\hline 9/17/2019 & 929.84 & None \\
\hline $9 / 18 / 2019$ & 929.91 & None \\
\hline 9/19/2019 & 929.94 & None \\
\hline 9/20/2019 & 929.95 & None \\
\hline $9 / 21 / 2019$ & 929.98 & None \\
\hline $9 / 22 / 2019$ & 930.14 & None \\
\hline 9/23/2019 & 930.15 & None \\
\hline $9 / 24 / 2019$ & 930.16 & None \\
\hline $9 / 25 / 2019$ & 930.18 & None \\
\hline $9 / 26 / 2019$ & 930.21 & None \\
\hline 9/27/2019 & 930.25 & None \\
\hline 9/29/2019 & 930.3 & None \\
\hline 9/30/2019 & 930.53 & None \\
\hline $10 / 1 / 2019$ & 930.62 & None \\
\hline $10 / 2 / 2019$ & 930.64 & None \\
\hline
\end{tabular}


Table 1.2. Erickson flowage elevations.-Continued

[NAVD 88, North American Vertical Datum of 1988; m/d/yyyy, date in month, day, year; <, below the bottom of the staff gage]

\begin{tabular}{|c|c|c|}
\hline Date & Flowage elevation, in feet above NAVD88 & Comments \\
\hline $10 / 3 / 2019$ & 930.68 & None \\
\hline $10 / 4 / 2019$ & 930.72 & None \\
\hline $10 / 6 / 2019$ & 930.88 & None \\
\hline $10 / 7 / 2019$ & 930.9 & None \\
\hline $10 / 8 / 2019$ & 930.92 & None \\
\hline $10 / 9 / 2019$ & 930.93 & None \\
\hline $10 / 10 / 2019$ & 930.94 & None \\
\hline $10 / 11 / 2019$ & 931 & None \\
\hline $10 / 14 / 2019$ & 931.06 & None \\
\hline $10 / 16 / 2019$ & 931.08 & None \\
\hline $10 / 18 / 2019$ & 931.08 & None \\
\hline $10 / 21 / 2019$ & 931.24 & None \\
\hline $10 / 22 / 2019$ & 930.86 & None \\
\hline $10 / 23 / 2019$ & 930.4 & None \\
\hline $10 / 24 / 2019$ & 929.7 & None \\
\hline $10 / 26 / 2019$ & 930.16 & None \\
\hline $10 / 28 / 2019$ & 930.2 & None \\
\hline $10 / 29 / 2019$ & 930.36 & None \\
\hline $10 / 30 / 2019$ & 930.48 & None \\
\hline $10 / 31 / 2019$ & 930.5 & None \\
\hline $11 / 4 / 2019$ & 930.62 & None \\
\hline $11 / 5 / 2019$ & 930.66 & None \\
\hline $11 / 11 / 2019$ & 929.54 & None \\
\hline
\end{tabular}




\section{Appendix 2. 2020 Well Data}

Additional data were collected in 2020 at a subset of the study wells. Data were collected before and after the flowages were lowered in 2020. The flowages were lowered by just under 2 feet. Graphs of the study data are shown in figure 2.1 with a vertical dashed line showing when the flowages were lowered. 

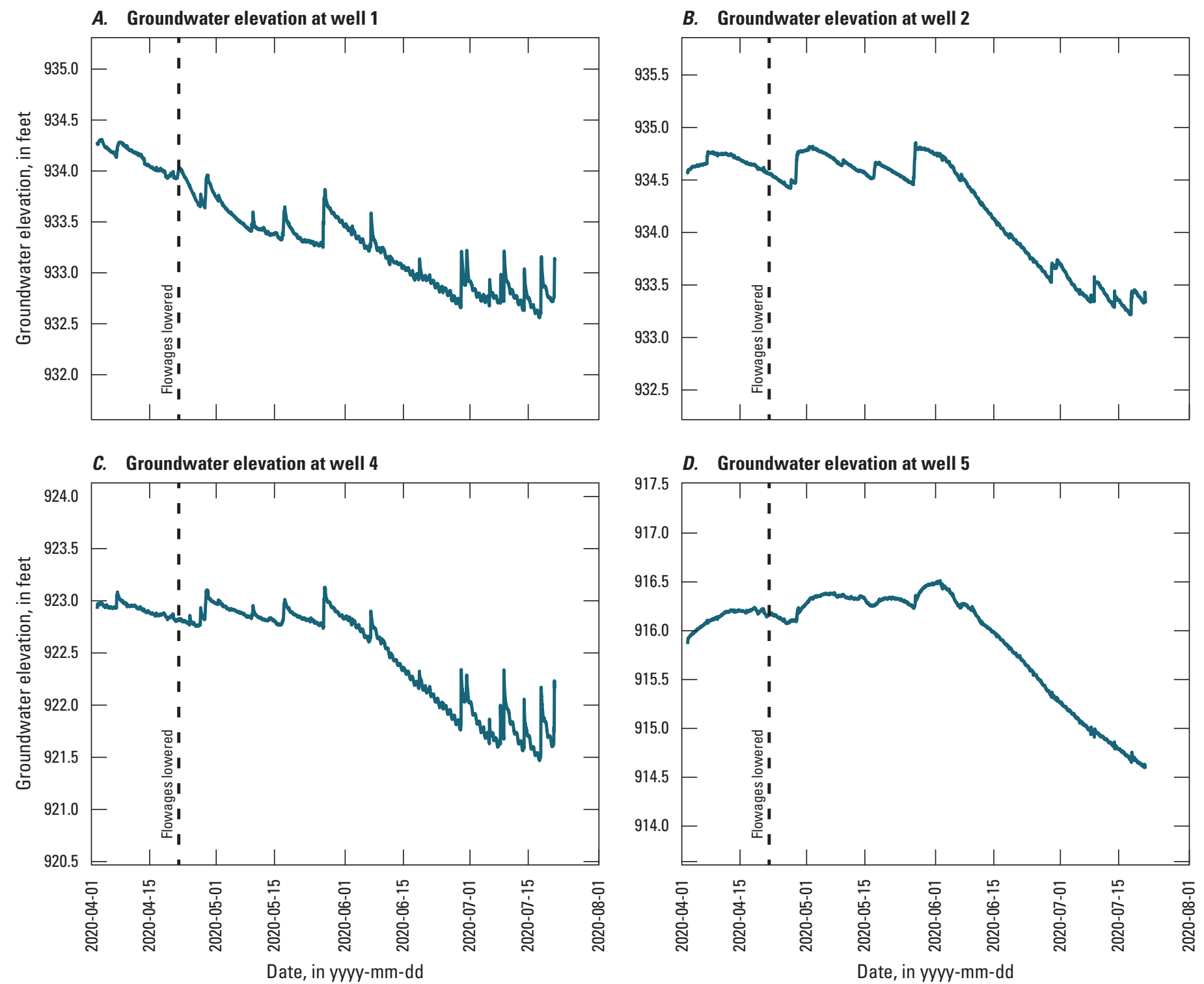

\section{EXPLANATION}

Groundwater elevation in well

Figure 2.1. Groundwater elevations for study monitoring wells collected in 2020. 

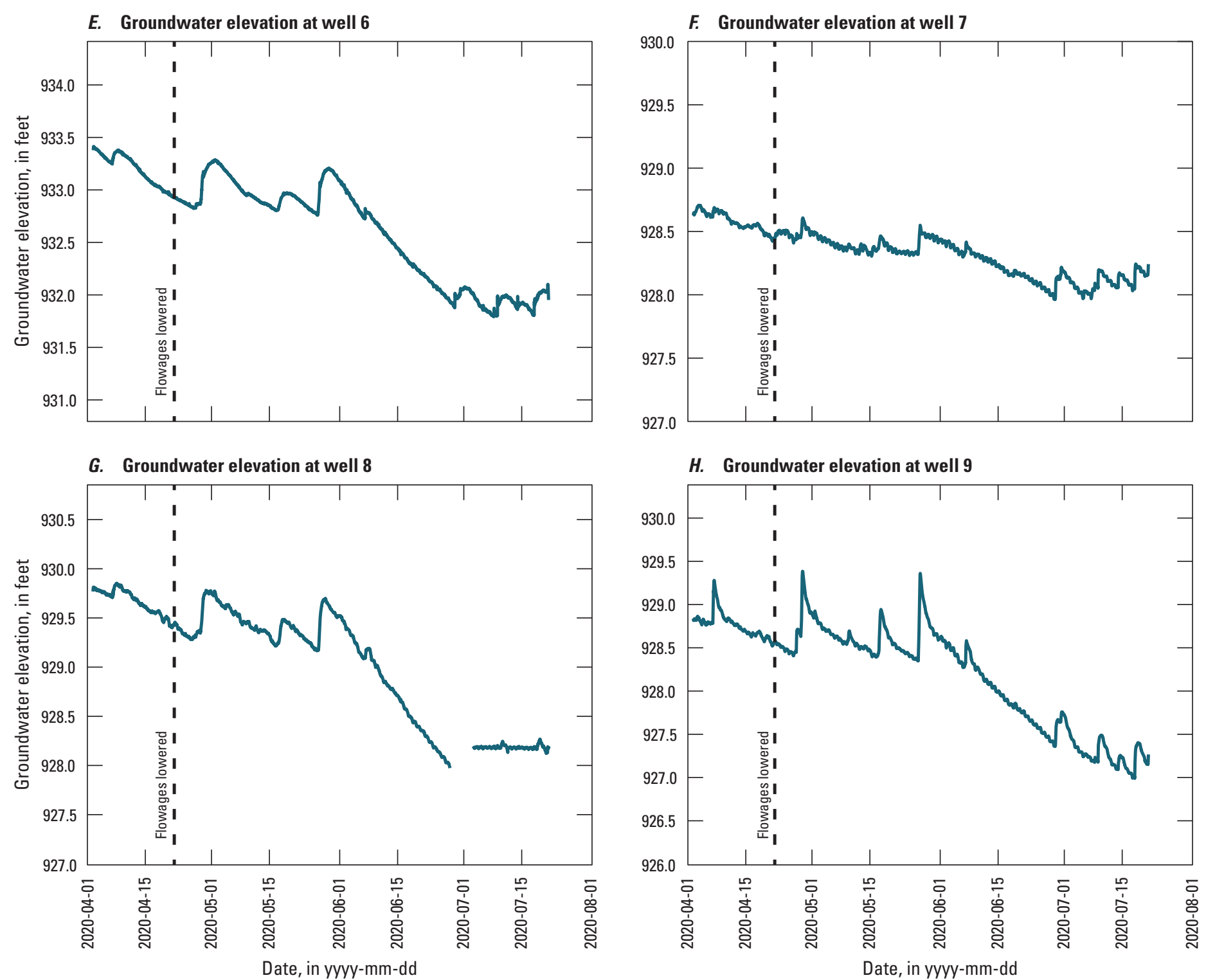

\section{EXPLANATION}

Groundwater elevation in well

Figure 2.1. Groundwater elevations for study monitoring wells collected in 2020.-Continued 

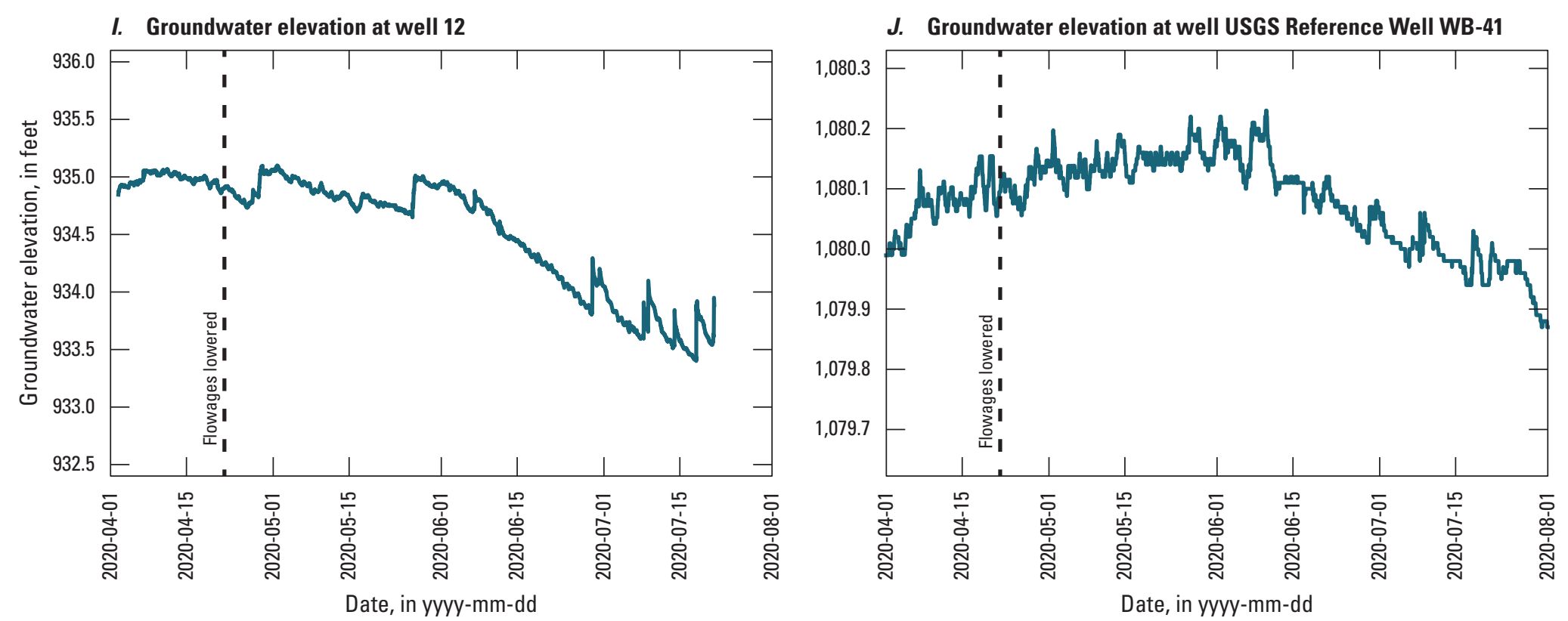

\section{EXPLANATION}

Groundwater elevation in well 
For additional information contact:

Director, USGS Upper Midwest Water Science Center

U.S. Geological Survey

8505 Research Way

Middleton, WI 53562

608-828-9901

For additional information, visit: https://www.usgs.gov/centers/ umid-water

Publishing support provided by the

Indianapolis Publishing Service Center 
